\title{
Structure of the Band-Shaped Precipitation System Inducing the Heavy Rainfall Observed over Northern Kyushu, Japan on 29 June 1999
}

\author{
Teruyuki KATO \\ Meteorological Research Institute, Tsukuba, Japan \\ (Manuscript received 20 January 2005, in final form 17 October 2005)
}

\begin{abstract}
A band-shaped precipitation system, associated with a cold front, caused heavy rainfall over northern Kyushu, Japan, on 29 June 1999. This precipitation system had a hierarchical structure with different horizontal scales; the precipitation system consisted of several mesoscale convective systems (MCSs), and each MCS consisted of a few convective cells that formed successively on its upstream side. Each of them had different spatial and time scales, as well as different traveling speeds and directions.

Low-level humid air from the southwest and middle-level dry air from the west continuously flowed into the precipitation system. This dry air was not colder than the surrounding atmosphere. The inflow of low-level humid air initiated the MCSs, and that of middle-level dry air enhanced, and maintained, the convective instability over the cold front. The heavy rainfall was brought under the maintenance condition of convective instability.

The cloud top heights of convective cells were found differently between the western and central parts of the precipitation system. The factors to determine them were examined using the successful simulation results of a nonhydrostatic cloud-resolving model, with the horizontal resolution of $2 \mathrm{~km}$. The intrusion of middle-level dry air into convective cells was considerably larger in the western part than in the central part. This caused the difference in the cloud top heights of the convective cells; the convective cells were less than $7 \mathrm{~km}$ high in the western part, whereas, in the central part, most were between 5 and $7 \mathrm{~km}$ high and at the height of the tropopause. In the western part, most of the convective cells completely lost their buoyancy because of the significant evaporative cooling of hydrometeors. These results show the two different effects of middle-level dry air; a huge amount inflow suppresses the development of convective cells, while it strongly enhances the convective instability.
\end{abstract}

\section{Introduction}

Heavy rainfall with an hourly accumulation of precipitation in excess of $50 \mathrm{~mm}$ has the potential to cause serious flooding and disasters. Such rainfall is frequently observed over Kyushu Island in western Japan during the Baiu season. The Baiu season is the rainy period from early June through the middle of July in East Asia. Most heavy rainfall events are

Corresponding author: Teruyuki Kato, Meteorological Research Institute, 1-1 Nagamine, Tsukuba, Ibaraki 305-0052, Japan.

E-mail: tkato@mri-jma.go.jp

(C) 2006, Meteorological Society of Japan caused by developed mesoscale convective systems (MCSs) with a band-shaped structure. Some band-shaped MCSs are observed aligning along a cold front associated with synoptic low pressure. Some are generated and maintained by the effect of the terrain (e.g., Yoshizaki et al. 2000a), and some develop suddenly over the Baiu frontal zone independently of synoptic disturbances and the terrain effect (e.g., Kato et al. 2003). In order to clarify the formation and maintenance mechanisms, and the structure of such band-shaped MCSs, some special field observations (e.g., TREX observation group 1998; Yoshizaki et al. 2000a; Yoshizaki et al. 2000b; Kato et al. 2003) have been performed during 
the Baiu season around Kyushu Island. In one of these observation (X-BAIU-99, Yoshizaki et al. 2000b) periods, MCSs formed and developed rapidly along a cold front on the western sea of Kyushu Island in the early morning of 29 June 1999. They were organized into a band-shaped precipitation system that caused heavy rainfall around the Fukuoka area, located in northern Kyushu Island. This heavy rainfall brought a flood that killed one person who could not escape from an underground market.

In order for heavy rainfall to form, atmospheric conditions must be suitable for convection cells to form successively. During the Baiu season, low-level humid air passing around the Pacific high-pressure zone flows into the Baiu frontal zone (Kato et al. 2003). After this air is lifted to the level of free convection (LFC) over the Baiu frontal zone, convective cells form and develop to the level at which they lose their buoyancy. The cloud top height of a convective cell is determined by the content of water vapor in the lifted air, and the temperature of the surrounding atmosphere. Such a consideration with regard to the development of convective cells is based on that of latent instability.

Latent instability is one consideration for the conditional instability, and it means the case that, when the temperature of air lifted from a lower layer is higher than that of the surrounding atmosphere, the low-level air is lifted adiabatically to the level of lifting condensation (LCL) and further along the moist adiabat, as in the case shown in Fig. 1. In other words, whenever there is an LFC, the atmosphere is latently unstable. The potential instability in relation with the convective available potential energy (CAPE) is one of the indexes determining the intensity of latent instability, and it is defined as the maximum vertical kinetic energy that convective cells can obtain. Many convective parameterization schemes use the concept of CAPE to implicitly treat the effect of convective cells (e.g., Fritsch and Chappell 1980). Moreover, since the upper-level water vapor is not considered to estimate the latent instability, convective parameterization schemes have been improved to introduce the upper data of the surrounding atmosphere into convective cells (e.g., Kain and Fritsh 1990).

On the other hand, when heavy rainfall occurred, dry air was often found in the middle-

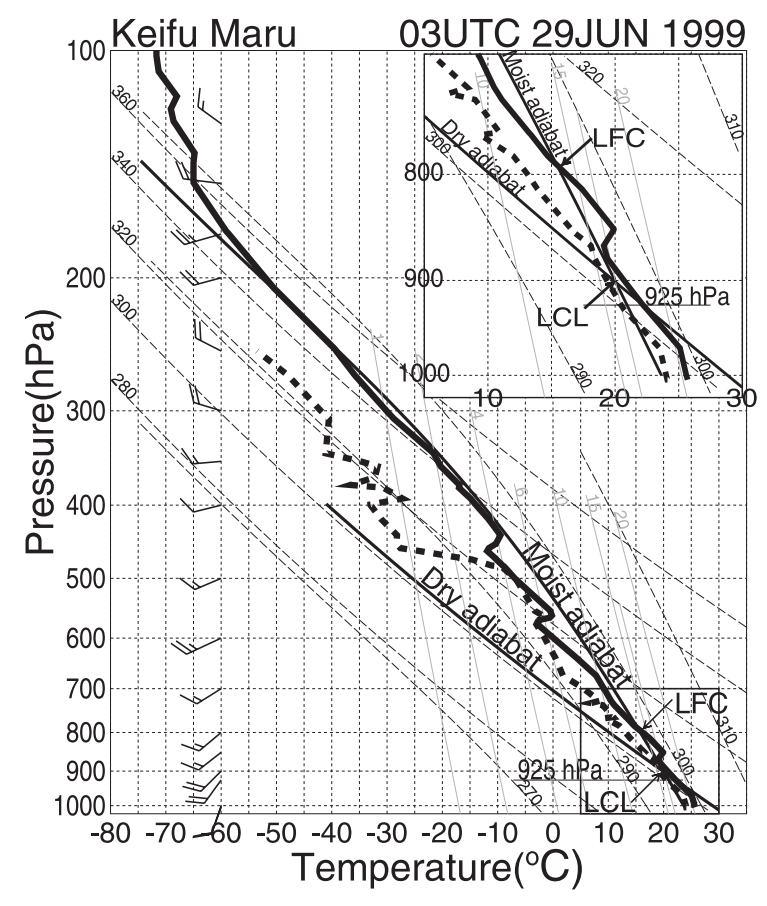

Fig. 1. Vertical profiles of temperature (thick solid line) and dew-point temperature (thick dashed line) observed at 03 JST on 29 June, from the observation vessel Keifu Maru, located at $30.7 \mathrm{~N}$ and 128.2 E. Arrows show observed horizontal winds. Full and half wind barbs indicate $10 \mathrm{~m} \mathrm{~s}^{-1}$ and $5 \mathrm{~m} \mathrm{~s}^{-1}$, respectively. The originating level to calculate the LCL and LFC is $925 \mathrm{hPa}$. The low-level profile is zoomed up in the left top panel.

level atmosphere (e.g., Kato and Aranami 2005). Such findings suggest that the concept of convective instability, which is defined from the vertical profile of the equivalent potential temperature, $\theta_{e}$, may be more useful than that of latent instability to clarify the maintenance mechanism of heavy rainfall. When the convective instability is estimated, the atmospheric instability is calculated using the total energy, including the thermal, potential, and latent energies. Consequently, the convective instability increases as the upper-level atmosphere becomes dry. Otherwise, to estimate the latent instability, it is necessary to know the temperature in the upper layer, but not the amount of water vapor. The above-mentioned explanations lead to the following relation: the $\theta_{e}$ dif- 
ference between $500 \mathrm{hPa}$ and $850 \mathrm{hPa}$, which represents the convective instability, is always smaller than the Showalter Stability Index (SSI), which represents the latent instability for SSI $<0$ (see Appendix). Here, the SSI is defined as the temperature difference at the $500 \mathrm{hPa}$ level, between the environmental atmosphere and the air lifted from the $850 \mathrm{hPa}$ level. This means that the atmospheric condition is often strong, convectively unstable, even when it is weak, latently unstable.

Incidentally, meteorological phenomena usually have a hierarchical structure with different horizontal scales. Previous studies (e.g., Kato and Goda 2001) showed that the MCSs consisted of a few convective cells and that several MCSs organized a band-shaped precipitation system with a length in excess of $200 \mathrm{~km}$. Such band-shaped precipitation systems sometimes cause heavy rainfall. However, little research has been conducted on the relationships among a band-shaped precipitation system, MCSs, and convective cells.

The primary purpose of this study is to clarify the maintenance mechanism of the heavy rainfall observed over northern Kyushu on 29 June 1999, by using the concept of convective instability. The atmospheric condition is usually estimated vertically in one dimension, using the upper-air sounding data, while, in this study, the convective instability is estimated in three-dimensional space using the objective analyses, and the results of numerical models.

The secondary purpose is to examine the structure of the MCSs causing the target heavy rainfall by using meteorological radar data, and the results of a cloud-resolving nonhydrostatic model. The MCSs that developed along the cold front caused the target heavy rainfall in a large-scale view, but cumulonimbi that had actually developed produced the strong precipitation. The relationship between the MCSs and convective cells is evaluated by examining their movements. Furthermore, the cause to determine the cloud top heights of convection cells, was examined from the viewpoint of the middle-level dry-air inflow into the target MCSs.

The contents of this paper are organized in the following manner. An overview of the target heavy rainfall, and the surrounding atmospheric condition is given in Section 2 . The hi- erarchical structure, with different horizontal scales in the target precipitation system, is examined in Section 3. The movements of meteorological disturbances (i.e., the cold front, MCSs, and convective cells) are studied using meteorological radar data. In Section 4, the manner in which the low-level wind field influences the traveling speed and direction of convective cells is examined. The numerical models used in this study, and their simulation results are described in Section 5. In Section 6, the vertical structure of the precipitation system is examined from the meteorological satellite data and the results of a cloud-resolving model. In Section 7, factors determining the cloud top heights of convective cells are discussed through sensitive numerical experiments. The summary and discussion are presented in the last section.

\section{Overview of the heavy rainfall and the environment in which it occurred}

The hourly accumulated Radar-AMeDASanalyzed rainfall chart at $08 \mathrm{JST}(=\mathrm{UTC}+9$ hours) on 29 June 1999 is shown in Fig. 2. The Radar-AMeDAS-analyzed rainfall is estimated by meteorological radars and calibrated by

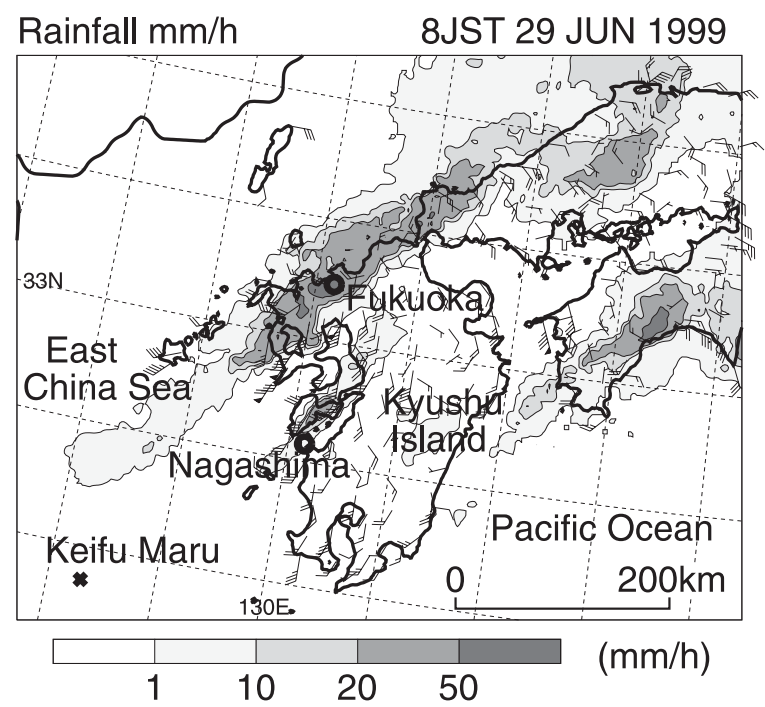

Fig. 2. Hourly accumulated RadarAMeDAS-analyzed rainfall chart at 08 JST on 29 June 1999. Arrows show observed surface winds. Full and half wind barbs indicate $5 \mathrm{~m} \mathrm{~s}^{-1}$ and $2.5 \mathrm{~m} \mathrm{~s}^{-1}$, respectively. 


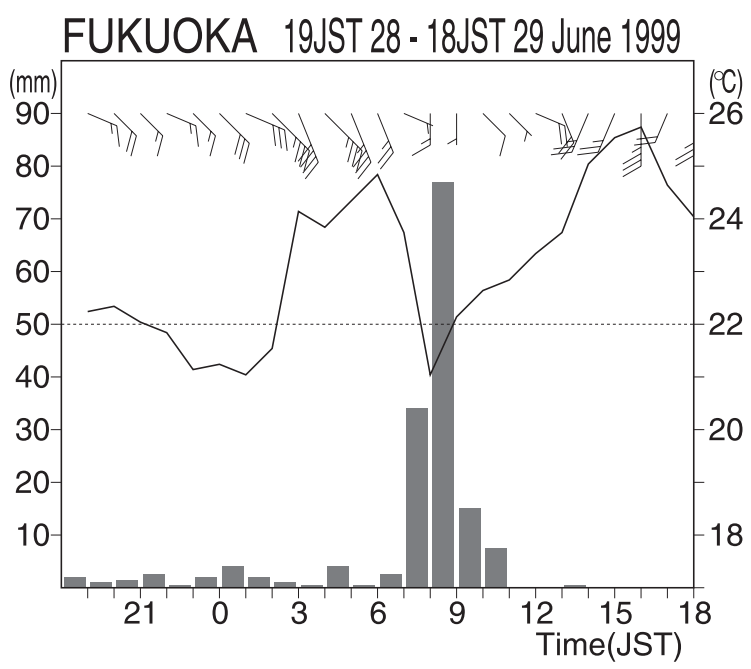

Fig. 3. Time series of observed hourlyaccumulated rainfall, temperature, and winds at Fukuoka between 19 JST 28 and 18 JST 29 June 1999. Full and half wind barbs indicate $5 \mathrm{~m} \mathrm{~s}^{-1}$ and $2.5 \mathrm{~m} \mathrm{~s}^{-1}$, respectively.

AMeDAS (Automated Meteorological Data Acquisition System) rain gauge observations of the Japan Meteorological Agency (JMA). A band-shaped rainfall area, with a length of about $400 \mathrm{~km}$, lay over the Fukuoka area in a southwest-to-northeast direction. Figure 3 shows the time series of hourly accumulated rainfall, temperature, and winds observed at Fukuoka between 19 JST 28 and 18 JST 29 June 1999. When the band-shaped rainfall area passed across Fukuoka, a maximum hourly accumulated rainfall of $95.5 \mathrm{~mm}^{1}$ was observed, and the temperature dropped by 4 degrees. This drop was caused by the evaporative cooling of raindrops in addition to the passage of the cold front. The surface weather map at 03 JST on 29 June before the heavy rainfall was observed is shown in Fig. 4. The band-shaped precipitation system causing the heavy rainfall at Fukuoka formed along a cold front. This cold front was associated with a meso- $\alpha$-scale low pressure that moved eastward over the East China Sea. A great amount of precipitation was concentrated in Fukuoka during approximately

1 The hourly rainfall in Fig. 3 accumulated between $00 \mathrm{~min}$ and the next $00 \mathrm{~min}$. This value was not accumulated in this manner.

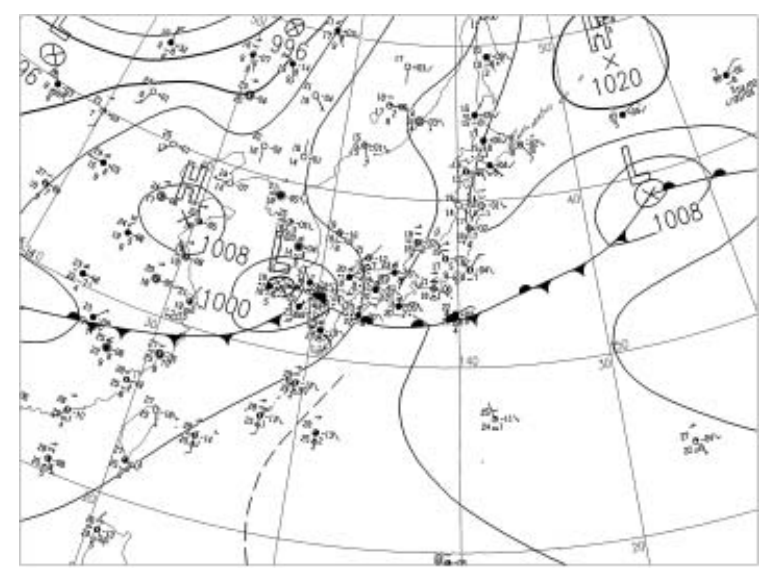

Fig. 4. Surface weather map at 03 JST on 29 June 1999.

one hour when this cold front passed (Fig. 3). The upper weather chart indicates a remarkable trough west of the meso- $\alpha$-scale low pressure (refer to Fig. 6a).

Infrared images of meteorological satellite GMS-5, between 02 JST and 04 JST on 29 June are shown in Fig. 5. At 02 JST, developed cloud systems, associated with the meso- $\alpha$-scale low pressure, were found around the Tsushima Islands but not the Goto Islands. Between 03 JST and 04 JST, new cloud systems formed and developed rapidly to the north of the Goto Islands. The location of these cloud systems corresponded to that of the analyzed cold front (Fig. 4). The MCSs that produced these cloud systems moved southeastward, and, after 4 hours, heavy rainfall hit Fukuoka.

The atmospheric condition to generate convective cells was examined, using uppersounding observations from the observation vessel Keifu Maru, located south of the cold front (Fig. 2). The vertical profiles of temperature and dew-point temperature (Fig. 1), observed at 03 JST on 29 June, show that the LCL of lifting air originating from $925 \mathrm{hPa}$ was at a level of about $900 \mathrm{hPa}$, and the LFC was at a level of about $790 \mathrm{hPa}$. From this originating level of $925 \mathrm{hPa}$, the CAPE of $772 \mathrm{~J} \mathrm{~kg}^{-1}$ can be calculated. This low-level atmospheric condition indicates that convective cells could form over the cold front with updrafts. It is noteworthy that dry air is found at above a $450 \mathrm{hPa}$ level, while the difference between the observed temperature, and the temperature in the lifted 


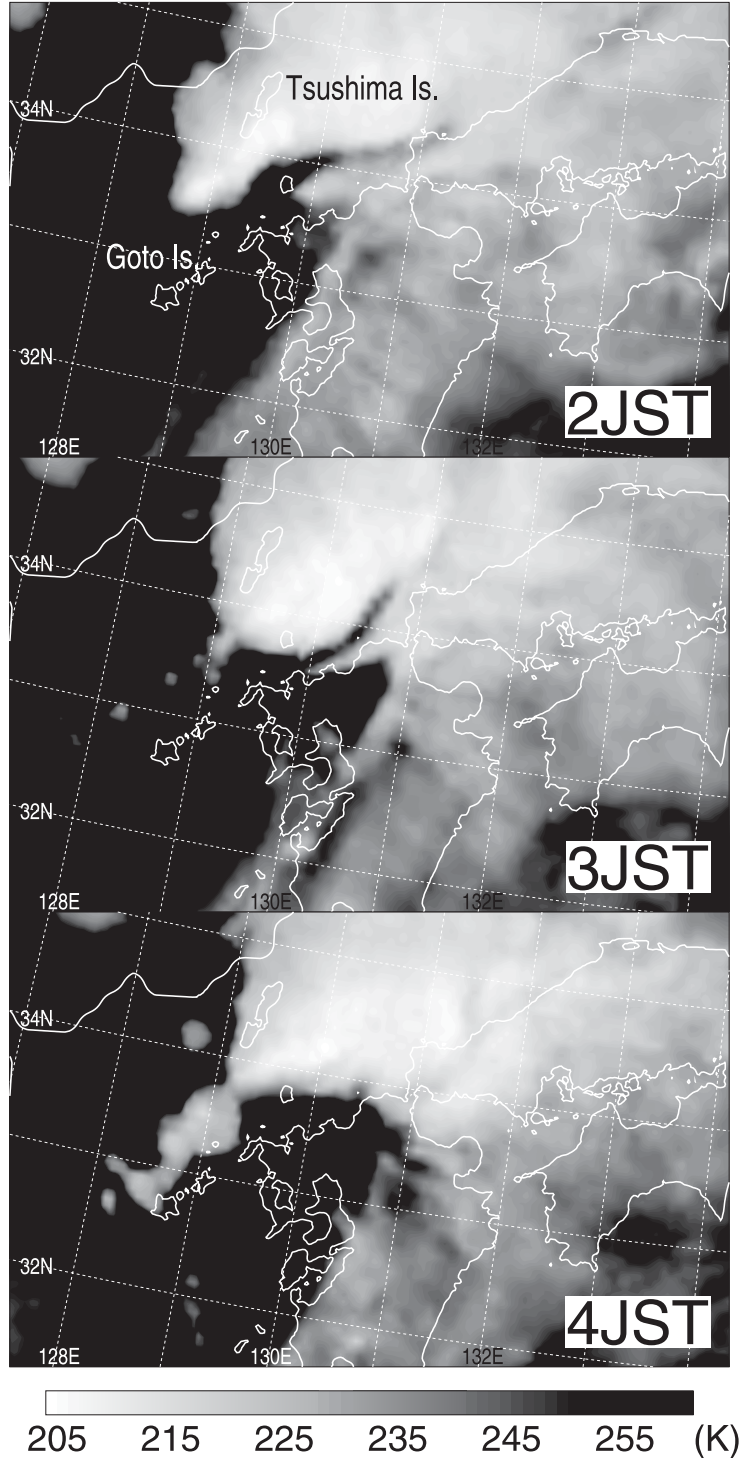

Fig. 5. Infrared images of meteorological satellite GMS-5 at 02 JST, 03 JST and 04 JST on 29 June 1999.

air originating from $925 \mathrm{hPa}$ is very small (Fig. 1). This small difference made CAPE a moderate value. Meanwhile, the middle-level dry air might play a significant role in the maintenance of the present heavy rainfall.

The $500 \mathrm{hPa}$-level and $925 \mathrm{hPa}$-level $\theta_{e}$ fields depicted from the JMA regional analysis (RANAL) at 09 JST on 29 June are shown in Fig. 6. At the $925 \mathrm{hPa}$ level, air with the $\theta_{e}$ larger than $340 \mathrm{~K}$ was transported to the meso- $\alpha$-scale low

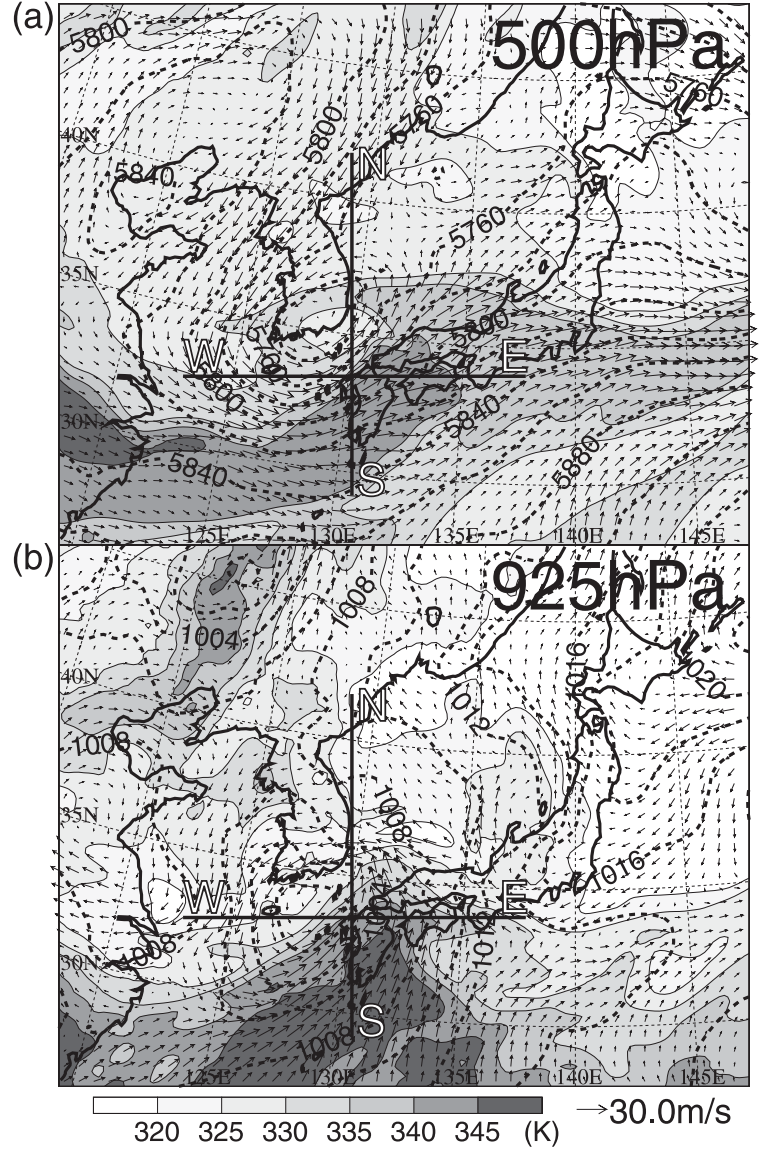

Fig. 6. (a) $500 \mathrm{hPa}$-level and (b) $925 \mathrm{hPa}$ level equivalent potential temperature fields depicted from the RANAL at 09 JST on 29 June 1999. Dashed lines in (a) denote the height with a contour interval of $20 \mathrm{~m}$, and those in (b) denote the sea level pressure with a contour interval of $2 \mathrm{hPa}$. Vectors show horizontal winds at the same level.

pressure by strong southwest winds. The northern edge of the area with southwest winds corresponded to the cold front, with a large gradient of $\theta_{e}$ and a strong wind convergence. This large gradient of $\theta_{e}$ was produced mainly by that of the potential temperature $\theta$ associated with the cold front (not shown). At the $500 \mathrm{hPa}$ level, air with the $\theta_{e}$ smaller than $330 \mathrm{~K}$, flowed from the west into the area over the cold front. To the south of this low $\theta_{e}$ air, a high $\theta_{e}(>340 \mathrm{~K})$ region with a width of about $500 \mathrm{~km}$, extended from southern China to the 
(a)

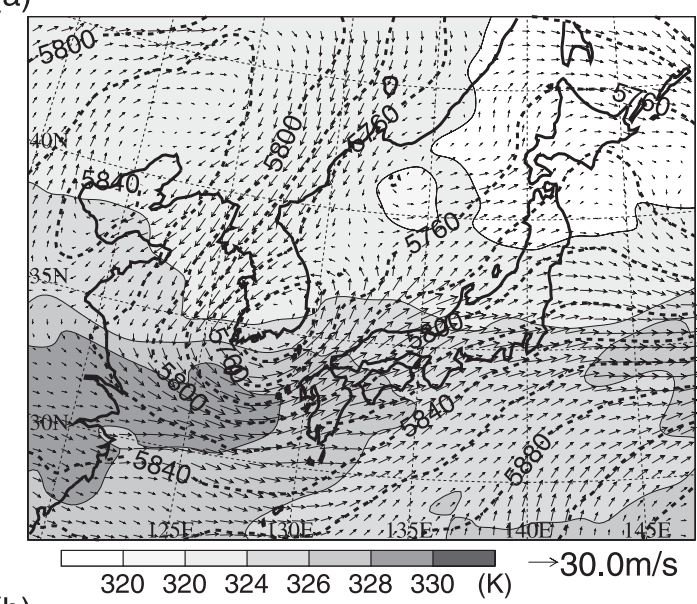

(b)

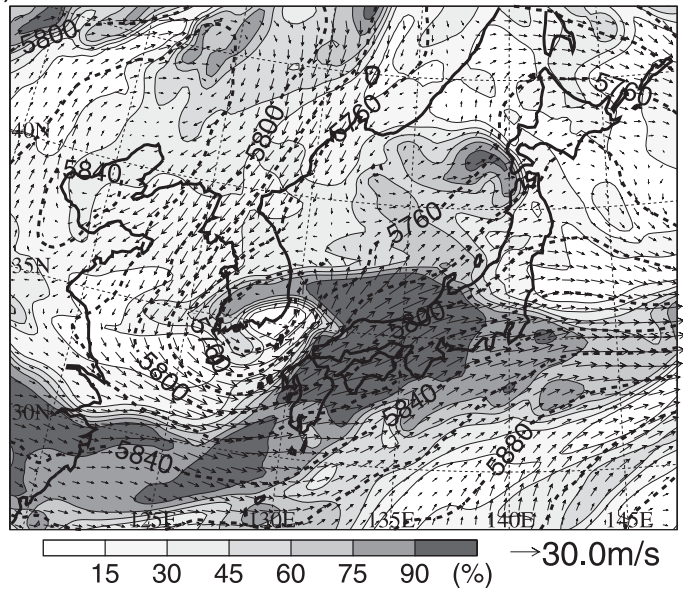

Fig. 7. Same as Fig. 6a, but for (a) the potential temperature and (b) the relative humidity.

Japan Islands. This high $\theta_{e}$ region, called a "moist tongue," was produced from the convective activities over the Baiu frontal zone.

The reason that the $\theta_{e}$ of the $500 \mathrm{hPa}$-level air, which flowed into the area over the cold front, was lower than that of the surrounding atmosphere is examined by checking the $\theta$ and water vapor fields. The $500 \mathrm{hPa}$-level $\theta$ and relative humidity fields depicted from the RANAL are shown in Fig. 7. The $\theta$ field (Fig. 7a) shows that the air flowing into the area over the cold front had higher $\theta$ than the surrounding atmosphere. The concept of latent instability explains that, in such a case, the atmospheric condition becomes stable rather than unstable. Meanwhile, the relative humidity field (Fig. 7b) shows that the pattern of its distribution around the cold front almost corresponded with that of the $\theta_{e}$, and that very dry air flowed into the area over the cold front. Therefore, the $500 \mathrm{hPa}$-level low $\theta_{e}$ condition over the cold front was produced from a dry air inflow, but not from a cold one. This means that the latent instability provides insufficient information to examine the maintenance mechanism of the present heavy rainfall. Therefore, the convective instability is better for those purposes.

The atmospheric conditions around the cold front are examined using the vertical profile of the $\theta_{e}$. The vertical cross sections of the $\theta_{e}$ along the lines E-W (in an east-west direction) and S-N (in a south-north direction) in Fig. 6 are shown in Fig. 8. The location of the cold front, with a low-level wind convergence is denoted with a dashed line. Over the cold front, the convectively unstable atmosphere was found locally below a $500 \mathrm{hPa}$ level, since the $\theta_{e}$ became lower with height there. The vertical cross section in an E-W direction (Fig. 8a) shows that northerly cold winds were predominant west of the cold front in the lower layer, and could transport the cold front to the south. Low $\theta_{e}$ air flowed from the west into the middle layer over the cold front. The vertical cross section in a S-N direction shows (Fig. 8b) that southwesterly winds transported humid air with high $\theta_{e}$ into the cold front. This humid air existed at a height exclusively below approximately $1.5 \mathrm{~km}(\sim 850 \mathrm{hPa}$ level). In such a case, in which low-level high $\theta_{e}$ air and middle-level low $\theta_{e}$ air continued to flow into the cold front, the convectively unstable atmospheric condition was maintained over the cold front. Under these environmentally atmospheric conditions, convective cells formed successively. Here, it should be noted that a convectively neutral layer with high $\theta_{e},(340-345 \mathrm{~K})$ existed just southeast of the cold front (Figs. $8 \mathrm{a}$ and $8 \mathrm{~b}$ ). This layer was produced by the transportation of the lifted $\theta_{e}$ air through the convective activities over the cold front, which suppressed the formation of convective cells to the south of the cold front. The lifted $\theta_{e}$ air was transported out of the area over the cold front, because the lowlevel and middle-level wind directions were different from each other (Figs. 6a and 6b). This difference in the wind directions played an im- 


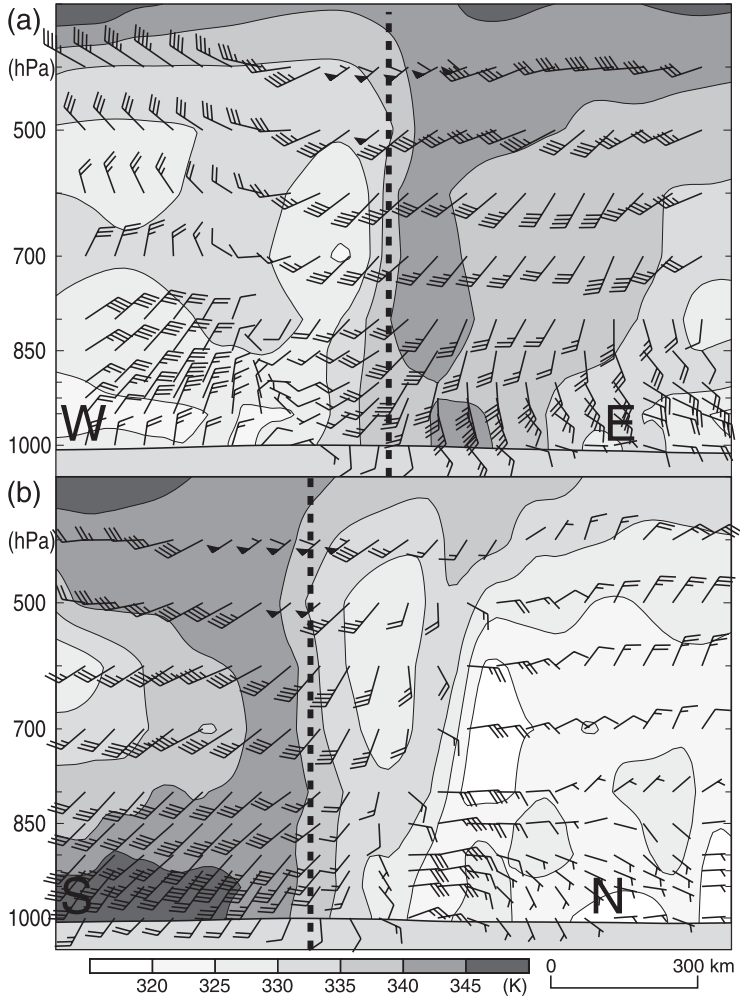

Fig. 8. The vertical cross section of the equivalent potential temperature along the lines (a) E-W and (b) S-N in Fig. 6. Full and half wind barbs indicate $5 \mathrm{~m} \mathrm{~s}^{-1}$ and $2.5 \mathrm{~m} \mathrm{~s}^{-1}$, respectively. Pennants indicate $25 \mathrm{~m} \mathrm{~s}^{-1}$. Dashed lines denote the position of the cold front with a low-level wind convergence. The scale bar shown in the rightbottom side denotes the length in an abscissa.

portant role in the maintenance of convectively unstable conditions over the cold front.

The wind speed exceeded $20 \mathrm{~m} \mathrm{~s}^{-1}$ to the south of the cold front over a $900 \mathrm{hPa}$ level. These strong winds have been called a "lowlevel jet," but they are called a "Baiu jet" here, as described in Kato (2005). Figure 9 shows the time-height cross section of the horizontal wind speed observed by upper-air sounding at Nagashima between 00 JST and 18 JST on 29 June. It is noted that, since Nagashima is located about $100 \mathrm{~km}$ south of Fukuoka, the cold front passed there about 3 hours later. At first, the wind speed accelerated to more than $30 \mathrm{~m} \mathrm{~s}^{-1}$ below a $900 \mathrm{hPa}$ level, and the vertical level with strong winds then shifted upward. These enhancement processes of the Baiu jet are the same as those in the heavy rainfall observed over southern Kyushu on 1 August 1993 (Kato 1998). The enhanced south-southeasterly lowlevel jet, below the Baiu jet could transport a great amount of water vapor into the MCSs over the cold front. This horizontal transportation of water vapor was one of the factors that caused the heavy rainfall observed around the Fukuoka area.

\section{Hierarchical structure with different horizontal scales in the precipitation system}

Meteorological phenomena usually have a hierarchical structure with different horizontal scales, such as synoptic disturbances and convective cells. For example, the meso- $\alpha$-scale low pressure, shown in Fig. 4, accompanied warm and cold fronts in which convective cells existed. The classification of large meteorological phenomena, such as synoptic disturbances and warm and cold fronts, is easy because their horizontal scales can be explained by theories, such as those for baroclinic waves and frontogenesis, and are usually depicted on a weather map. Meanwhile, the horizontal scale of convective cells, which are the smallest of all meteorological disturbances related to precipitation processes, is comparable with their vertical scale. However, a hierarchical structure with horizontal scales smaller than those of synoptic disturbances has not been clarified. MCSs consist of convective cells, but the factors to determine their horizontal and time scales have not been understood yet. In this study, a hierarchical structure including MCSs is examined by tracing the movements of the cold front, MCSs, and convective cells that were observed by meteorological C-band radar.

The time-series of the maximum precipitation intensity observed by meteorological radar in south-north, and east-west directions around the cold front are shown in Figs. 10a and 10b, respectively. Representative movements of MCSs and convective cells are shown by solid and dashed vectors. The time interval of radar observations was 7.5 minutes. At first, a large area with strong precipitation intensity is easily found moving southward at a speed of 


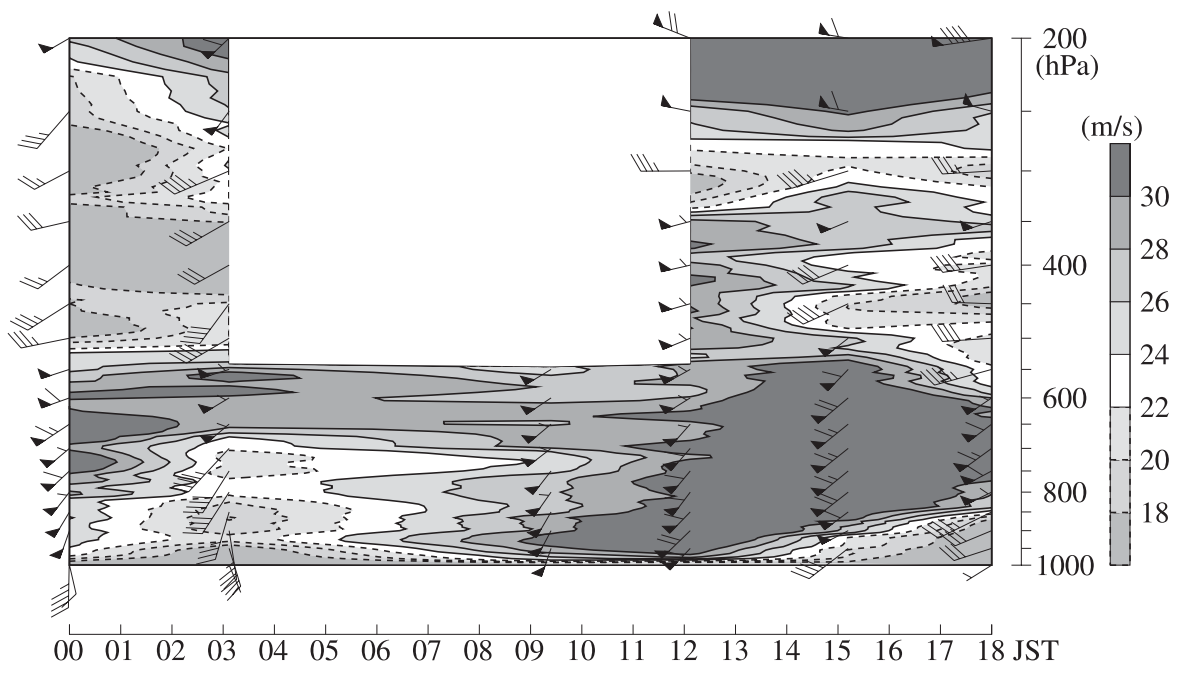

Fig. 9. Time-height cross section of the horizontal wind speed observed by upper-air sounding at Nagashima between 00 JST and 18 JST on 29 June 1999. Full and half wind barbs indicate $5 \mathrm{~m} \mathrm{~s}^{-1}$ and $2.5 \mathrm{~m} \mathrm{~s}^{-1}$, respectively. Pennants indicate $25 \mathrm{~m} \mathrm{~s}^{-1}$.

$5 \mathrm{~m} \mathrm{~s}^{-1}$, and eastward slowly. This movement corresponds with that of the cold front. In addition, many line-shaped areas are seen traveling northward and eastward, and each of them corresponds to movements of convective cells, with a time scale of about one hour and a horizontal scale of about $10 \mathrm{~km}$. The traveling distance of convective cells can be estimated from their lifetime and traveling speed. Each convective cell can be seen traveling northward at a speed of about $15 \mathrm{~m} \mathrm{~s}^{-1}$, and eastward at a speed of about $20 \mathrm{~m} \mathrm{~s}^{-1}$ in Figs. 10a and 10b, respectively. Therefore, the traveling distance of convective cells can be estimated at about $100 \mathrm{~km}$.

In Figs. 10a and 10b, a third movement, shown by solid vectors, can be seen overlapping the movements of the cold front and convective cells. The aggregates of convective cells with this movement were traveling at a speed of about $12 \mathrm{~m} \mathrm{~s}^{-1}$ and $10 \mathrm{~m} \mathrm{~s}^{-1}$ in the south-north and east-west directions, respectively. This speed is slower than that of convective cells. These aggregates correspond to MCSs with the meso- $\beta$-scale, since their time and horizontal scales are $3 \sim 5$ hours and about $100 \mathrm{~km}$, respectively. During the period shown in Fig. 10, MCS-a and MCS-b are representative and lasted for 5 hours. Three or four MCSs always existed over the cold front. New convective cells formed successively on the upstream side of each MCS with an interval of about 30 minutes (see MCS-c in Fig. 10b), although their formation cannot be clear in some MCSs due to the overlap of other movements, and the rough classification of the precipitation intensity. These results indicate that the structure of the MCSs had the characteristic features of a multi-cell type. This successive formation mechanism of convective cells could be the same as that described in Kato (1998).

From the traveling vectors and speed of the cold front, convective cells, and MCSs in the east-west and south-north directions shown in Fig. 10c, the precipitation system causing heavy rainfall around the Fukuoka area had a hierarchical structure with three different horizontal scales. Each of the meteorological disturbances, with a different horizontal scale, not only had a different time scale but also traveled in a different direction at a different speed. The horizontal scale of MCSs consisting of convective cells $(\sim 100 \mathrm{~km})$ can almost be estimated from the lifetime and traveling distance of convective cells. Meanwhile, it is very difficult to find factors to determine the time scale of MCSs, because each lifetime of an MCS is different from that of another MCS. The vertical profile and shear of horizontal environmental winds, and their vertical rotation effect, could 
(a)

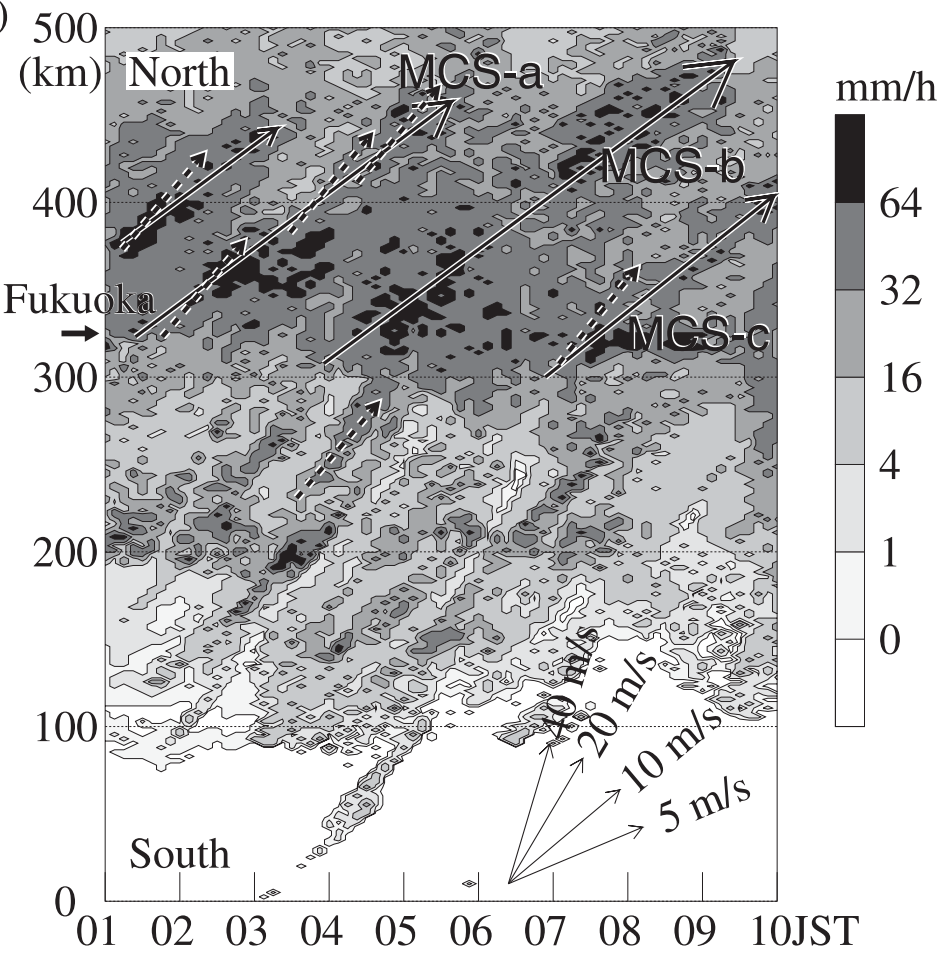

(b)

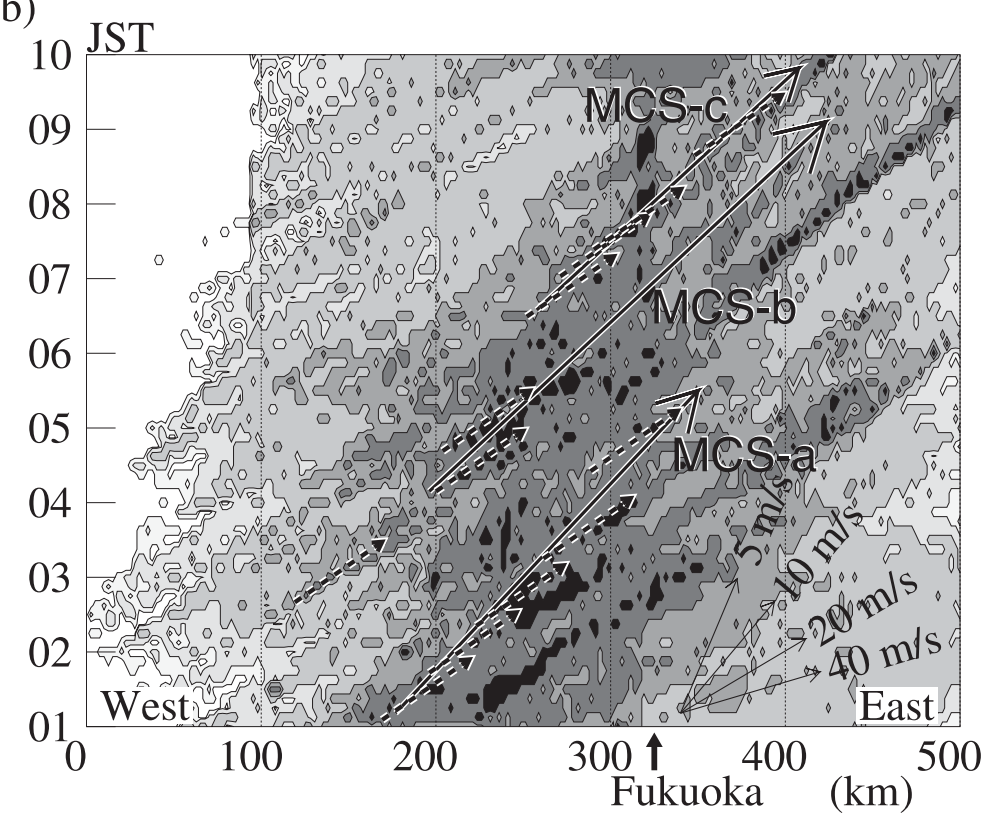

Fig. 10. Time-series of the maximum precipitation intensity observed by meteorological C-band radar in (a) south-north and (b) east-west directions between 01 JST and 10 JST on 29 June 1999. These figures are drawn using the maximum precipitation intensity on the line across the cold front in east-west and south-north directions, respectively. Each line has a length of about $100 \mathrm{~km}$, whose center is almost located at the cold front. Observation interval was 7.5 minutes. The traveling speed can be measured by explanatory remarks shown with vectors in the right-side bottom of each panel. Representative movements of MCSs and convective cells are denoted by solid and dashed vectors, respectively. 


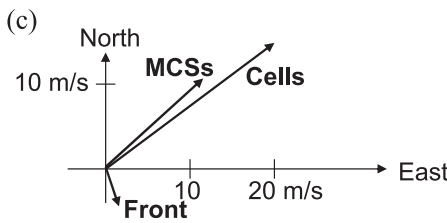

\begin{tabular}{l|ll} 
& \multicolumn{1}{|c}{ w-e direction } & n-s direction \\
\hline Front & eastward $2 \mathrm{~m} / \mathrm{s}$ & southward $5 \mathrm{~m} / \mathrm{s}$ \\
MCSs & eastward $12 \mathrm{~m} / \mathrm{s}$ & northward $10 \mathrm{~m} / \mathrm{s}$ \\
Cells & eastward $20 \mathrm{~m} / \mathrm{s}$ & northward $15 \mathrm{~m} / \mathrm{s}$
\end{tabular}

Fig. 10. (c) Traveling vectors of the cold front, convective cells, and MCSs, and their speeds in southnorth and east-west directions.

be the factors used to determine the time scale of the MCSs, but they are always changed by the mesoscale processes. Therefore, it is not easy to find factors to determine the time scale of the MCSs in simple parameters, such as the vertical profile and shear of horizontal environmental winds.

\section{Influence of the low-level wind field on the traveling speed and direction of convective cells}

The manner in which the low-level wind field influences the traveling speed and direction of convective cells is examined here. Their speed and direction can be fundamentally determined by the flow of the middle-level atmosphere because the gravity center of convective cells usually exists in the middle layer. Meanwhile, convective cells form by low-level humid air arriving at the LFC. This indicates that convective cells hold the lifted horizontal momentum from the lower layer until their mature stage because they accompany the updrafts produced by lifted low-level humid air. Therefore, the traveling speed and direction of convective cells can also be determined from the low-level wind field if the lifted horizontal momentum from the lower layer is conserved in convective cells.

Both the wind speeds of the low-level humid inflow and the middle-level atmosphere around the cold front were about $20 \mathrm{~m} \mathrm{~s}^{-1}$, and their wind directions were south-southwestward and westward, respectively (see Figs. 7 and 8). These directions are not different from the traveling direction of convective cells, estimated from Fig. 10. The traveling direction of convective cells is found between the wind directions at the lower and middle levels. This indicates that the movement of convective cells is considerably affected by both the low-level humid inflow, and the middle-level atmosphere around the cold front.
In this section, for the sake of convenience, it is assumed that the movement of convective cells corresponds to that of lifted low-level humid air, and the atmosphere is treated as the Boussinesq fluid. The forcing received by the lifted air is examined in two layers, with two horizontal wind vectors of the low-level wind flowing into the cold front, and the middle-level environmental wind, $\mathbf{v}_{L}$ and $\mathbf{v}_{M}$, as shown in Fig. 11. This assumption is based on the movement of convective cells that are accompanied with updrafts produced by lifted low-level hu-

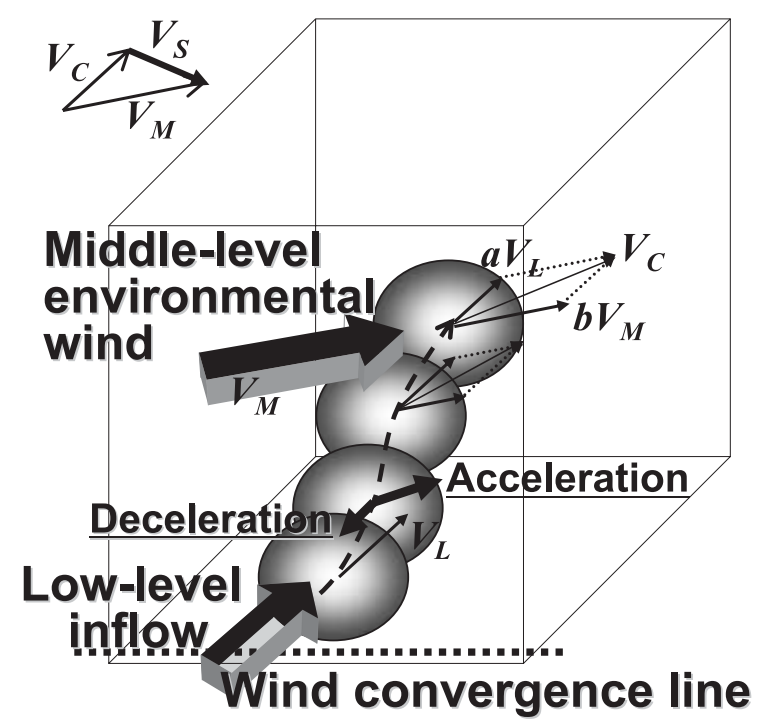

Fig. 11. Schematic diagram on the determination of the traveling speed and direction of the air parcel lifted from the lower layer, shown by circles. $\mathbf{v}_{c}, \mathbf{v}_{L}$ and $\mathbf{v}_{M}$ denote the traveling vector of convective cells, and the horizontal wind vectors of the low-level inflow and the middle-level environmental wind, respectively. $a$ and $b$ are coefficients to be satisfied less than 1 . Wind Shear vector between the lower and middle layers $\mathbf{v}_{s}$ is shown in the left top side. 
mid air. This is because the lifted air is located around the top area of the updrafts. The traveling vector, $\mathbf{v}_{c}$, of convective cells can be expressed by $\mathbf{v}_{L}$ and $\mathbf{v}_{M}$ as

$$
\mathbf{v}_{c}=a \mathbf{v}_{L}+b \mathbf{v}_{M},
$$

where $a$ and $b$ are coefficients.

Lifted low-level air that flows into convective cells, forming over a near-surface wind convergence line, maintains its horizontal momentum at first. Until the lifted air loses its buoyancy, it receives some forcing to change its horizontal momentum, such as the pressure gradient force, the Coriolis force, and mixing with the circumambient atmosphere. The effect of the Coriolis force is minimal, because the time scale of convective cells is less than one hour. The pressure gradient force between convective cells and their circumambient atmosphere produced by diabatic heating also exerts a slight effect on the horizontal momentum, because the pressure drop occurs only within convective cells. In other words, the gradient force on the upstream side and that on the downstream side of convective cells cancel each other out. Therefore, only the forcing on the horizontal momentum of the lifted air from the environmental flow is only examined in this section.

The above-mentioned forcing is assumed to be proportional to the wind shear vector, between $\mathbf{v}_{c}$ and $\mathbf{v}_{M}$, defined as $\mathbf{v}_{s}$, as shown on the left top side of Fig. 11. This assumption means that the lifted air is accelerated in the direction of $\mathbf{v}_{s}$. Therefore, the horizontal momentum equations for the lifted air can be written as

$$
\frac{d \mathbf{v}_{c}}{d t}=P G F=\alpha\left(\mathbf{v}_{M}-\mathbf{v}_{c}\right) .
$$

Here, $P G F$ is the pressure gradient force, and $\alpha$ is the constant that satisfies $1 \gg \alpha>0$. The initial condition of Eq. (2) is

$$
\mathbf{v}_{c}=\mathbf{v}_{L} \quad \text { for } t=0 .
$$

From Eqs. (2) and (3), $\mathbf{v}_{c}$ is solved as

$$
\mathbf{v}_{c}=e^{-\alpha t} \mathbf{v}_{L}+\left(1-e^{-\alpha t}\right) \mathbf{v}_{M} .
$$

The time-differential of Eq. (4) is expressed as

$$
\frac{d \mathbf{v}_{c}}{d t}=-\alpha e^{-\alpha t} \mathbf{v}_{L}+\alpha e^{-\alpha t} \mathbf{v}_{M} .
$$

Equation (5) means that the lifted air loses some of the horizontal momentum in the low- level wind direction (first term on the righthand side), while it receives the momentum from the environmental flow (second term) through the dynamic pressure gradient force. Therefore, the lifted air receives acceleration in the direction of $\mathbf{v}_{M}$ and deceleration in the direction of $\mathbf{v}_{L}$ from the environmental flow, as shown by the vectors marked with the symbols "Acceleration" and "Deceleration" in Fig. 11. In addition, such a decrease of $\mathbf{v}_{L}$ and an increase of $\mathbf{v}_{M}$ are also caused by the mixing of the horizontal momentum with that of the circumambient atmosphere.

From Eqs. (1) and (4), $a+b=1$ is obtained. However, the actual wind field is not built of two layers at the low and middle levels, and the above-mentioned consideration is also based on the assumption of the Boussinesq fluid. Therefore, $a+b=1$ does not need to be satisfied in an actual case, and the coefficents of $a$ and $b$ can then be understood less than 1 . In the present case, the traveling speed of convective cells estimated with the radar observation (Fig. $10 \mathrm{c}$ ) is about $25 \mathrm{~m} \mathrm{~s}^{-1}$, which is faster than those of the low-level south-southwesterly and middle-level westerly winds ( $\sim 20 \mathrm{~m} \mathrm{~s}^{-1}$, Fig. 8). Both the constants of $a$ and $b$ can be estimated at about 0.7 in the present case. The examination in this section indicates that the low-level wind field strongly influences the traveling speed, and direction of convective cells. However, a detailed examination on what determines the traveling speed and direction of convective cells should be conducted using idealized numerical experiments.

\section{Numerical models and simulation results}

\section{a. Specifications of numerical models}

The nonhydrostatic model developed by the Meteorological Research Institute (MRI-NHM; Saito 1997 and Saito et al. 2001) was nested within the forecast of the JMA regional spectral model (RSM) with a horizontal grid of $20 \mathrm{~km}$ [Numerical Prediction Division (NPD)/JMA 2002]. The MRI-NHM used in this study is the full compressible version, in which the density is calculated directly from the state equation without any approximation. The sound waves were treated implicitly in both the horizontal and vertical directions. The model specifications used in this study are summarized in 
Table 1. Specifications of MRI-NHM

\begin{tabular}{|c|c|}
\hline Categories & $\begin{array}{l}\text { Specifications used in the } \\
\text { present study [See Saito } \\
\text { (1997) and Saito et al. } \\
\text { (2001) for specifications } \\
\text { without reference] }\end{array}$ \\
\hline Basic equations & $\begin{array}{l}\text { Fully compressible with a } \\
\text { map factor }\end{array}$ \\
\hline $\begin{array}{l}\text { Vertical } \\
\text { coordinate }\end{array}$ & $\begin{array}{l}\text { Terrain-following (Gal-Chen } \\
\text { and Somerville 1975) }\end{array}$ \\
\hline $\begin{array}{l}\text { Horizontal } \\
\text { coordinate }\end{array}$ & $\begin{array}{l}\text { Polar-stereo graphic tangent } \\
\text { plane }\end{array}$ \\
\hline \multirow{4}{*}{ Advection scheme } & Arakawa C grid \\
\hline & $\begin{array}{l}\text { Flux form, second order } \\
\quad \text { (Clark 1977) }\end{array}$ \\
\hline & $\begin{array}{l}\text { Box-Lagrangian raindrop } \\
\text { scheme (Kato 1995) }\end{array}$ \\
\hline & $\begin{array}{l}\text { Modified advection scheme } \\
\text { (Kato 1998) }\end{array}$ \\
\hline $\begin{array}{l}\text { Treatment of } \\
\text { sound wave }\end{array}$ & $\begin{array}{l}\text { Vertically and horizontally } \\
\text { implicit for sound waves }\end{array}$ \\
\hline Turbulent closure & Level 2.5 \\
\hline $\begin{array}{l}\text { Precipitation } \\
\text { scheme }\end{array}$ & $\begin{array}{l}\text { Cold rain scheme, predicting } \\
\text { the mixing ratios of cloud } \\
\text { water, cloud ice, } \\
\text { rainwater, snow and } \\
\text { graupel (Ikawa and Saito } \\
\text { 1991) }\end{array}$ \\
\hline $\begin{array}{l}\text { Atmospheric } \\
\text { radiation }\end{array}$ & $\begin{array}{l}\text { Calculating long and short } \\
\text { waves using cloud amount } \\
\text { measured from relative } \\
\text { humidity }\end{array}$ \\
\hline Surface layer & $\begin{array}{l}\text { Monin-Obukhov (Sommeria } \\
\text { 1976), Kondo (1975) }\end{array}$ \\
\hline Lower boundary & $\begin{array}{l}\text { Forecasting the ground } \\
\text { temperature using a } 4 \text { - } \\
\text { layer model over the land, } \\
\text { and fixing sea surface } \\
\text { temperature over the land }\end{array}$ \\
\hline Upper boundary & $\begin{array}{l}\text { Thermally rigid lid insulated } \\
\text { Rayleigh friction layer }\end{array}$ \\
\hline Lateral boundary & $\begin{array}{l}\text { Radiative nesting boundary } \\
\text { condition }\end{array}$ \\
\hline $\begin{array}{l}\text { Numerical } \\
\text { diffusion }\end{array}$ & $\begin{array}{l}\text { 4-th order linear horizontal } \\
\text { damping }\end{array}$ \\
\hline
\end{tabular}

Table 1. Bulk-method type microphysics with the ice phase was used in the MRI-NHM as precipitation processes; on the other hand, two parameterized convective schemes, i.e., the prognostic Arakawa-Schubert scheme (NPD/ JMA, 2002), and the moist convective adjustment scheme (Gadd and Keers 1970), were

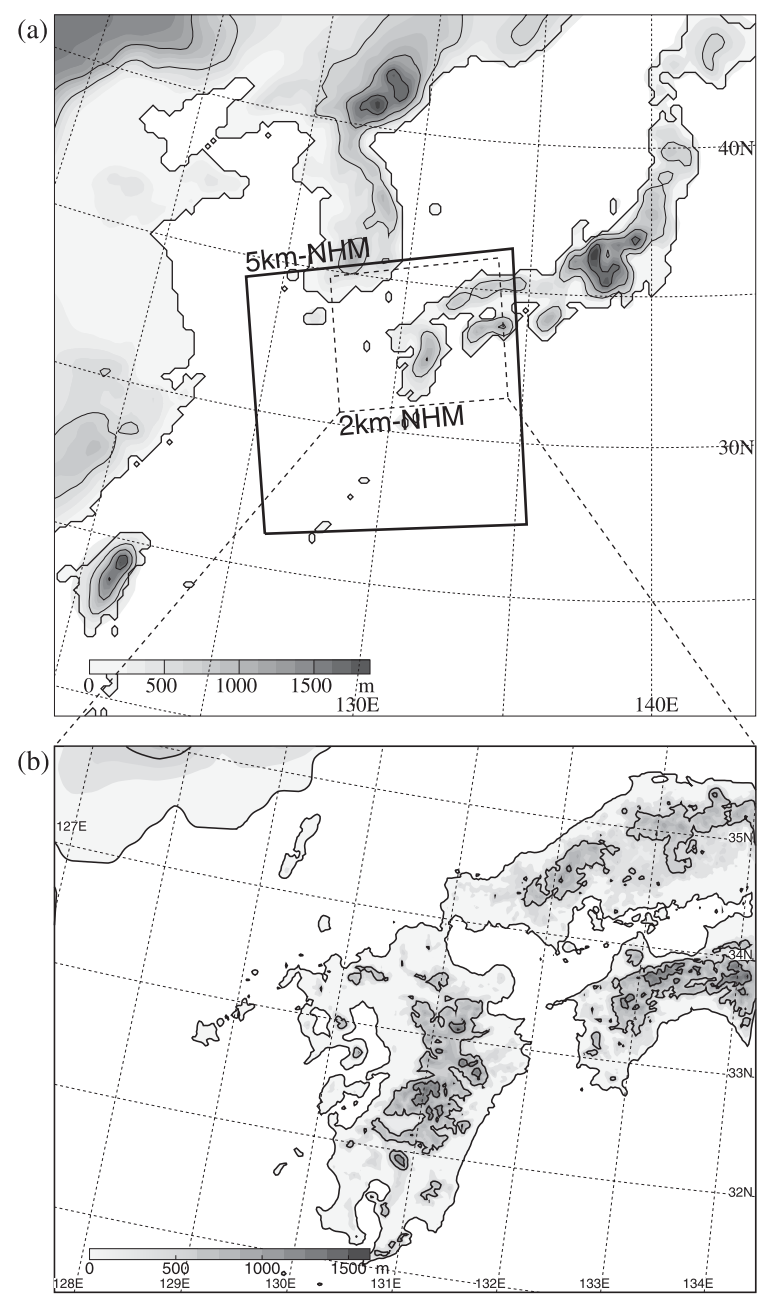

Fig. 12. (a) Domain and topography of the RSM. Rectangles with solid and dashed lines denote the domains of $5 \mathrm{~km}-\mathrm{NHM}$ and $2 \mathrm{~km}-\mathrm{NHM}$, respectively. (b) Same as (a), but for the $2 \mathrm{~km}$ NHM. Lambert map projection is used in the RSM, while polar stereo one in the NHMs.

used in conjunction with large-scale condensation in the RSM.

\section{b. Designs of the numerical simulations}

The domain and topography of RSM used in this study are shown in Fig. 12a. The domain of RSM had $129 \times 129$ grid points in the horizontal direction, and 36 layers in the vertical one. For the MRI-NHM, horizontal grid sizes of $2 \mathrm{~km}$ and $5 \mathrm{~km}$ were used. The MRI-NHMs with $2-\mathrm{km}$ and $5-\mathrm{km}$ horizontal grids are here- 
after abbreviated as $2 \mathrm{~km}-\mathrm{NHM}$ and $5 \mathrm{~km}$ NHM, respectively. The horizontal domains of $2 \mathrm{~km}-\mathrm{NHM}$ and $5 \mathrm{~km}-\mathrm{NHM}$, respectively, covered $650 \times 530 \mathrm{~km}^{2}$ and $1000 \times 1000 \mathrm{~km}^{2}$, while the vertical grid contained 38 levels, with variable grid intervals of $40 \mathrm{~m}$ (near the surface) to $1120 \mathrm{~m}$ (at the top of the domain). The model top was located at $19.82 \mathrm{~km}$. The domain and topography of $2 \mathrm{~km}-\mathrm{NHM}$ are shown in Fig. 12b. The solid square box in Fig. 12a shows the domain of $5 \mathrm{~km}-\mathrm{NHM}$.

First, the JMA regional analysis field at 21 JST on 28 June 1999, the initial condition of the RSM, was numerically integrated within the forecasts of the JMA global spectral model (NPD/JMA 2002) as the boundary conditions. Next, the $5 \mathrm{~km}-\mathrm{NHM}$ was one-way nested within the forecasts of the RSM, and the $2 \mathrm{~km}$ NHM was then one-way nested within the forecasts of the $5 \mathrm{~km}-\mathrm{NHM}$ as well. The initial conditions of both models were interoperated from the forecasts of the coarse-mesh model. The initial time of the $5 \mathrm{~km}-\mathrm{NHM}$ was $00 \mathrm{JST}$, and that of $2 \mathrm{~km}-\mathrm{NHM}$ was $03 \mathrm{JST}$ on 29 June.

\section{c. Simulated rainfall distribution}

The hourly accumulated rainfall distributions predicted by the RSM and $2 \mathrm{~km}-\mathrm{NHM}$ at 08 JST 29 June are shown in Fig. 13. The RSM predicted rainfall over northern Kyushu (Fig. 13a). However, the areas were spread more widely than in the observation (Fig. 2), and the maximum precipitation amount there was less than $10 \mathrm{~mm}$. This prediction did not show the occurrence of heavy rainfall. Meanwhile, the rainfall distribution predicted by the $2 \mathrm{~km}$ NHM (Fig. 13b), almost agreed with the observation (Fig. 2), and the band-shaped rainfall area associated with the cold front was well reproduced. The predicted maximum hourly rainfall of $123 \mathrm{~mm}$, almost agreed with the observation as well.

The movements of MCSs, and convective cells were detected using the meteorological radar observation, with an interval of 7.5 minutes in the last section (Figs. 10a and 10b). Here, these movements are also examined using the $2 \mathrm{~km}-\mathrm{NHM}$ simulation results with an interval of one minute. Figures $14 \mathrm{a}$ and $14 \mathrm{~b}$ show the time series of the maximum rainwater mixing ratio predicted by the $2 \mathrm{~km}-\mathrm{NHM}$ in the south-north and east-west directions, re-
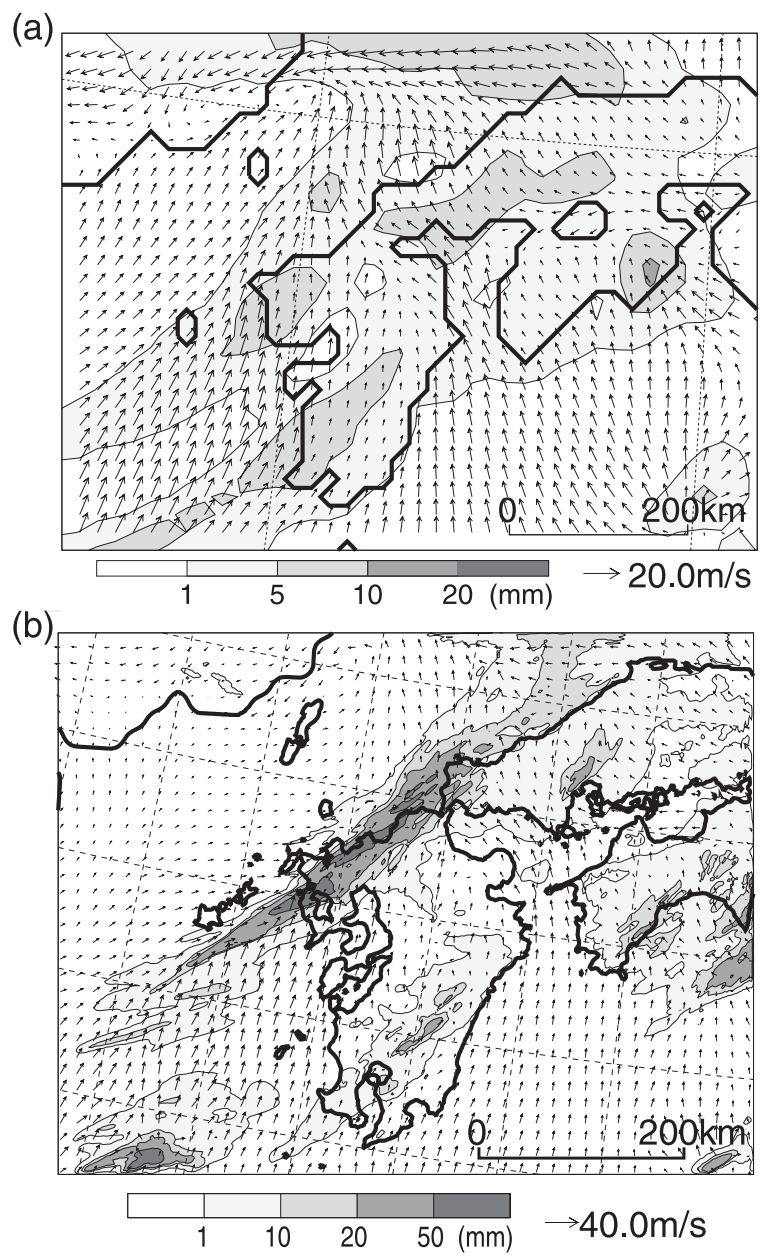

Fig. 13. Same as Fig. 2, but for the predictions of (a) RSM and (b) 2 km-NHM. Vectors show the near-surface horizontal winds.

spectively, around the cold front. Almost identical movements were reproduced by the $2 \mathrm{~km}$ NHM, although those of the MCSs showed a slightly different traveling direction from that of the radar observation (Figs. 10c and 14c). The movements of the MCSs are easily found, in comparison with those in Figs. 10a and 10b. This agreement indicates that the successful reproduction of both convective cells and MCSs, was essential to predict heavy rainfall.

\section{Vertical structure of the band-shaped precipitation system}

In order to examine the vertical structure of the band-shaped precipitation system, the 

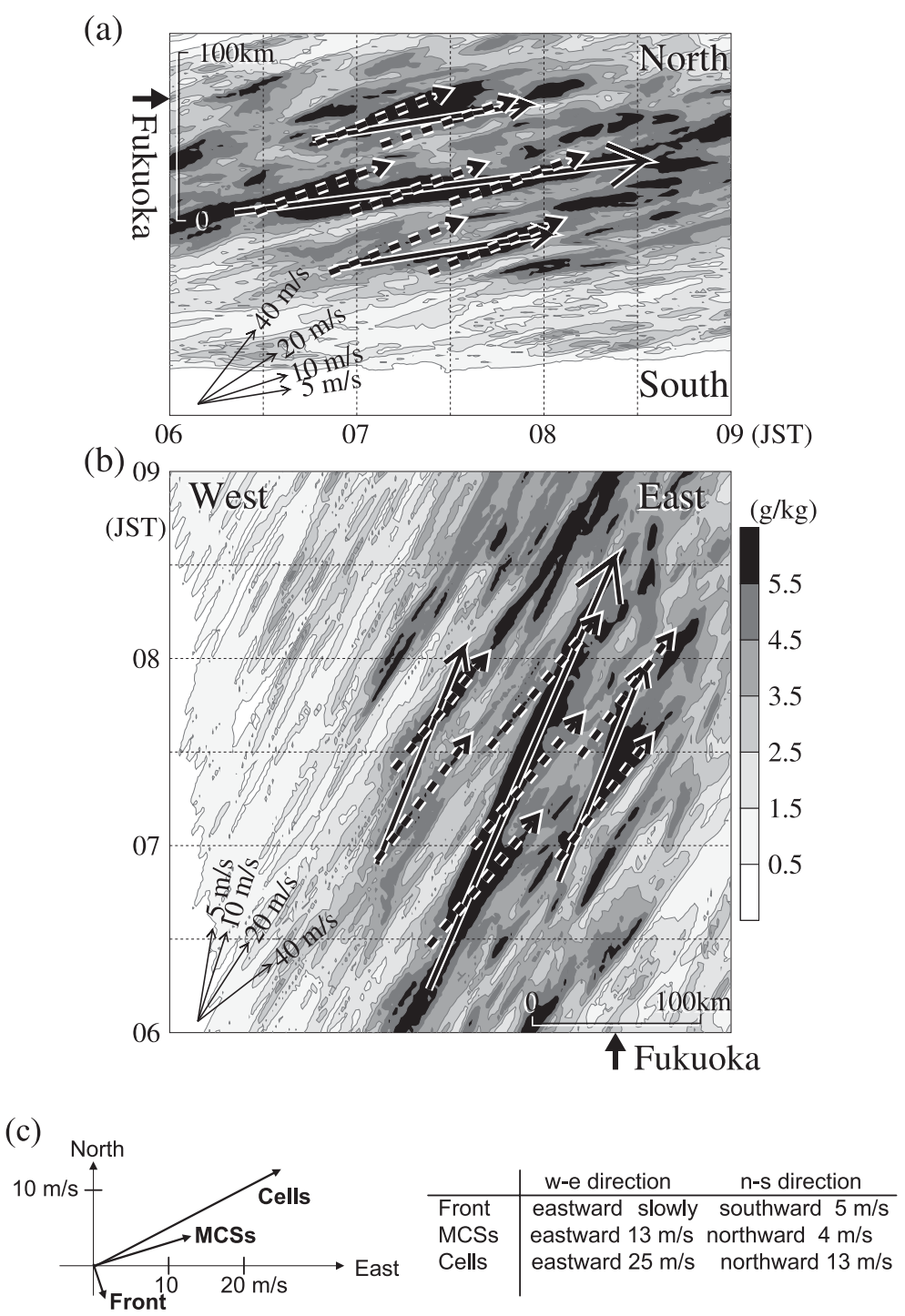

Fig. 14. Same as Fig. 12a, but for the maximum rainwater mixing ratio predicted by the $2 \mathrm{~km}-\mathrm{NHM}$. These figures are drawn using the same method as that for Figs. 10a and 10b, but for the maximum rainwater mixing ratio in vertical cores instead of the precipitation intensity. The scale bars in (a) and (b) denote the length in an ordinate and an abscissa, respectively.

cloud top heights of convective cells are first estimated from the brightness temperature observed by the meteorological satellite GMS-5. Figure 15 shows the hourly Radar-AMeDASanalyzed rainfall distributions, and observed infrared brightness temperature at $06 \mathrm{JST}, 07$ JST, and 08 JST on 29 June 1999. The heights corresponding to the brightness temperature, estimated from the upper-air sounding at $\mathrm{Fu}-$ kuoka at 09 JST on 29 June, are shown on the right-hand side of Fig. 15. The band-shaped precipitation system, associated with the cold front, advanced southeastward and reached the Fukuoka area at 08 JST (Fig. 15a). Then, the strongest precipitation hit Fukuoka. This strongest precipitation area, denoted by the solid circles shown in Fig. 15, is called the central part (CP) hereafter. Meanwhile, in the western part of the cold front, denoted by the dashed circle in Fig. 15 (hereafter, abbreviated WP), the precipitation intensity was considerably weaker than that in the CP. 

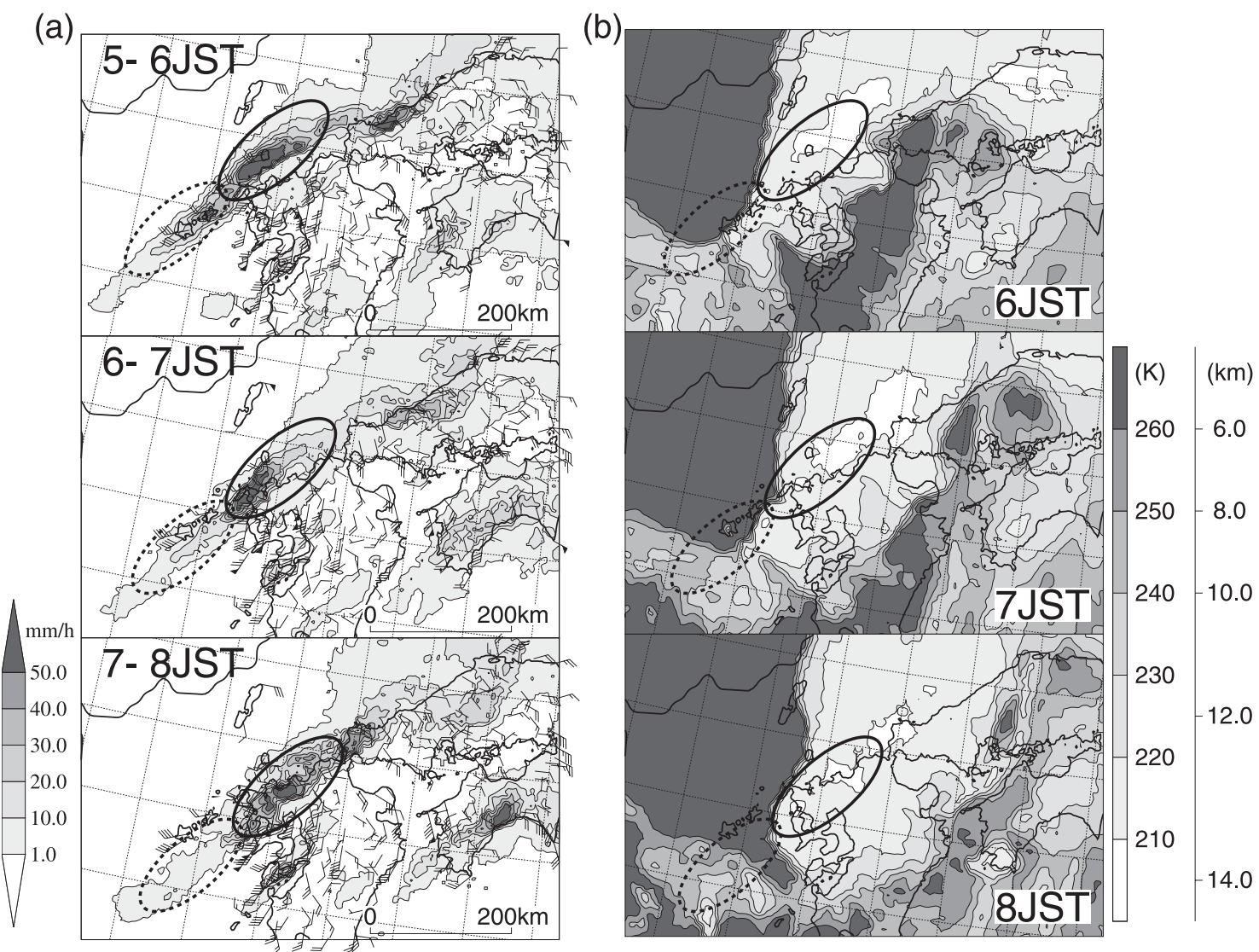

Fig. 15. (a) Same as Fig. 2, but at 06 JST, 07 JST and 08 JST. (b) Infrared brightness temperature observed by the meteorological satellite GSM-5 at the same time of (a). The heights corresponding to the brightness temperature, estimated from the upper-air sounding observation at Fukuoka at 09 JST on 29 June, are denoted by the scale shown at the right side of figures. Solid and dashed circles divide the rainfall area associated with the cold front into the central and western parts, respectively.

The cloud top heights of these two areas are compared. The cloud top heights in the CP were estimated to exceed $12 \mathrm{~km}$, because the brightness temperature was less than $220 \mathrm{~K}$ (Fig. 15b). This indicates that developed convective cells caused the heavy rainfall observed around the Fukuoka area. Meanwhile, since the brightness temperature was higher than $260 \mathrm{~K}$ in some areas of the WP, shallow convective cells, with cloud tops of less than $6 \mathrm{~km}$ were observed there. These differences between the CP and the WP are also ascertained by the observation numbers of lightning around the band-shaped precipitation system (not shown). A significant amount of lightning was observed in the CP; however, this was rare in the WP.
The collision between ice particles and graupels is necessary for the formation of lightning (Takahashi 1984). This collision can occur in developed convective cells, such as those that appeared in the CP. Incidentally, it is necessary to determine the reason for the difference in the cloud top heights between the CP and the WP. This issue can be resolved by using the simulation results of the $2 \mathrm{~km}-\mathrm{NHM}$.

In this study, convective cells are assumed to exist in vertical grids with predicted updraft exceeding $2.0 \mathrm{~m} \mathrm{~s}^{-1}$. The cloud top heights of convective cells are determined by those at which the vertical velocity changes from positive to negative values. These heights must be higher than those of the maximum vertical 
(a)

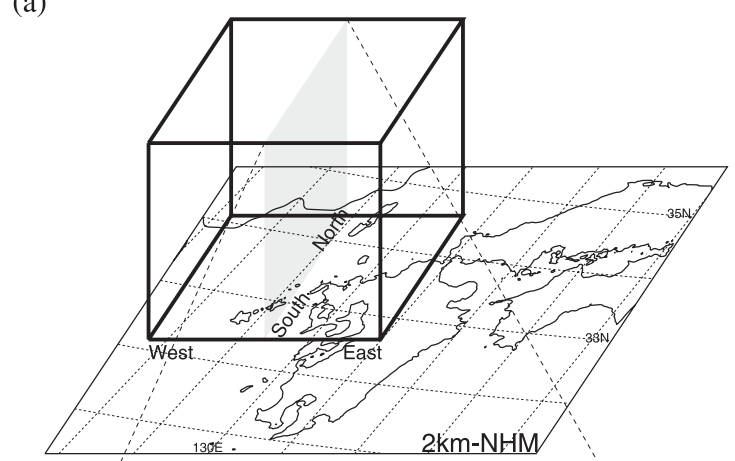

(b)

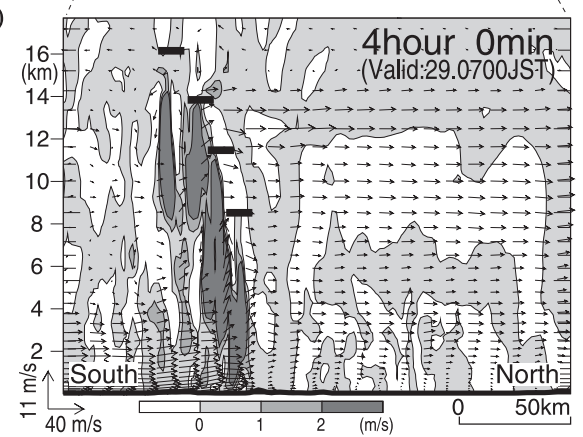

Fig. 16. (a) Domain, shown by the box with thick lines, in which cloud top heights of convective cells were estimated from the simulation results of the $2 \mathrm{~km}-\mathrm{NHM}$. (b) Example of determining cloud top heights from the vertical cross section of vertical velocity in a south-north direction. Arrows show the wind vectors projected on this cross section. Thick lines denote the cloud top heights determined by the top of updrafts with a vertical velocity exceeding $2 \mathrm{~m} \mathrm{~s}^{-1}$.

velocity. Examples of cloud top heights determined by this method are denoted by thick lines in Fig. 16b.

Since it is very difficult to determine the cloud top heights of convective cells by Lagrangian-tracing all simulated convective cells, the appearance rates of the cloud top heights of convective cells in an east-west direction were calculated as follows. First, the cloud top heights of the convective cells simulated by the $2 \mathrm{~km}-\mathrm{NHM}$ were categorized every $500 \mathrm{~m}$ in height. Then, a number in each category was averaged in a south-north direction in the domain, denoted by the box with thick solid lines in Fig. 16a. Most of such convective cells

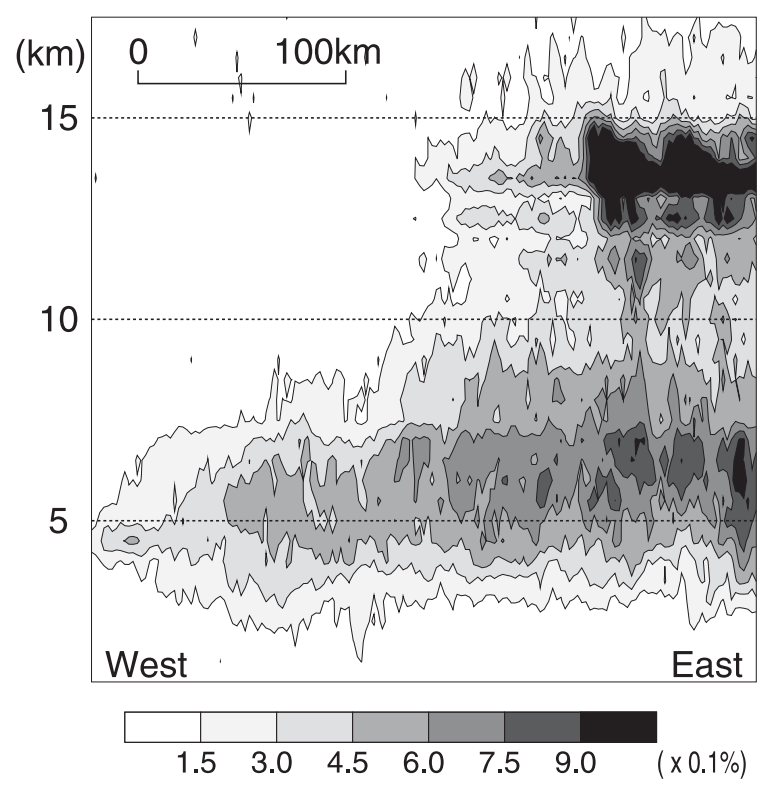

Fig. 17. Appearance rate distribution of cloud top heights of convective cells in an east-west direction. This rate was averaged in a south-north direction shown in Fig. 16a and between 06 JST and 09 JST on 29 June. The scale bar shown in the left-top side denotes the length in an abscissa.

with updrafts exceeding $2.0 \mathrm{~m} \mathrm{~s}^{-1}$ formed in association with the band-shaped precipitation system over this domain (not shown). Further, a number in each category was also averaged during the period when the heavy rainfall was observed, from 06 JST to 09 JST on 29 June.

The appearance rate distribution of the cloud top heights of convective cells in an east-west direction, obtained by the above-mentioned method, is shown in Fig. 17. In the WP, most of the cloud top heights of the simulated convective cells were less than $7 \mathrm{~km}$. Meanwhile, many of the developed convective cells arriving at the tropopause, about $14 \mathrm{~km}$ altitude, were found in the CP. These results correspond with those estimated from the satellite observations (Fig. 15b). In the CP, it is noted that the secondary peak of the appearance rate continuously connects to the peak in the WP at a height of $5 \mathrm{~km}$ to $7 \mathrm{~km}$. This indicates that shallow convective cells were also found in the CP. The characteristic features of these results are never changed in the appearance rate dis- 
tribution of cloud top heights averaged for a shorter time (i.e., 15-30 minutes, not shown).

These characteristic features of the cloud top heights of convective cells are the same as those obtained by a sensitive experiment, without the ice-phase in precipitation processes (not shown). Therefore, the buoyancy produced by two latent heat releases, due to condensation and freezing, was not the factor that resulted in the formation of the two peaks in the cloud top heights of convective cells in the CP. Then, it would be interesting to determine what caused the difference in the cloud top heights of convective cells between the $\mathrm{CP}$ and the WP, and what produced the two peaks in the CP. In other words, the factor causing the cloud top heights of convective cells should be determined. In the next section, the circumambient atmospheric conditions of convection cells are examined to clarify these issues.

\section{Factors to determine the cloud top heights of convection cells}

\section{a. Circumambient atmospheric conditions of} convection cells

The $2 \mathrm{~km}$-NHM-predicted $\theta_{e}$ fields at 07 JST on 29 June at the lower, middle, and upper levels are shown in Fig. 18. These levels roughly correspond to heights of $0.5 \mathrm{~km}, 5 \mathrm{~km}$, and $10 \mathrm{~km}$, respectively. High $\theta_{e}$ air from the southwest, and low $\theta_{e}$ air from the west, continuously flowed into the area over the cold front at the lower and middle levels (Figs. 18a and 18b), respectively. As mentioned in Section 2 , convective cells formed successively under the atmospheric condition with strong convective instability that was maintained by the continuous inflow of low $\theta_{e}$ air above high $\theta_{e}$ air. This successive formation of convective cells was one of the factors causing the heavy rainfall. Ten $\mathrm{km}$-horizontal-scale areas, with $\theta_{e}$ higher than $346 \mathrm{~K}$, are found adjacent to the low $\theta_{e}$ air at the middle level (Fig. 18b). Each of these areas corresponded to one of the convective cells, because high $\theta_{e}$ air was lifted from the lower layer by updrafts. The areas where convective cells were simulated corresponded to those where the heavy rainfall was predicted (Fig. 15a). This indicates that the formation of developed convective cells with higher cloud top was also one of the factors to cause the heavy rainfall. However, areas with $\theta_{e}$ higher than

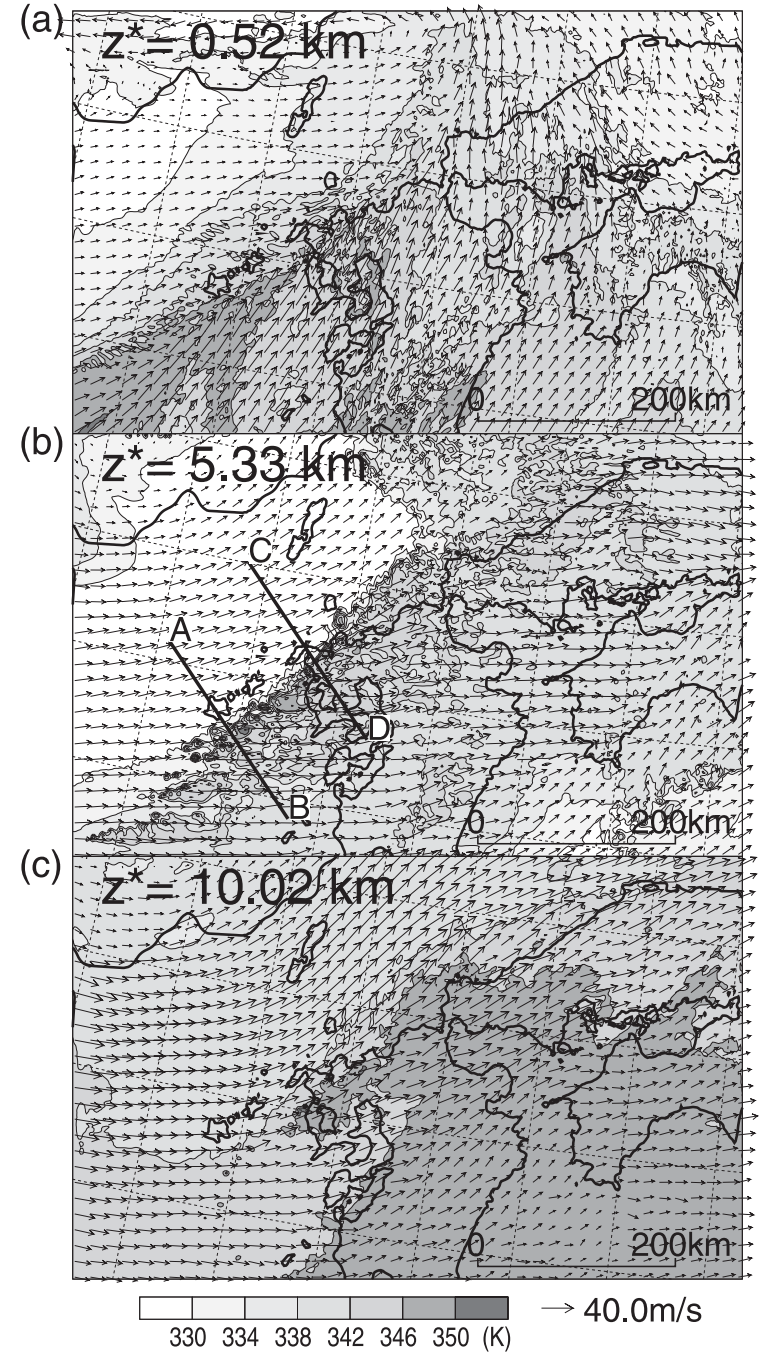

Fig. 18. Equivalent potential temperature fields predicted by the $2 \mathrm{~km}-\mathrm{NHM}$ at $z^{*}=$ (a) $0.52 \mathrm{~km}$, (b) $5.33 \mathrm{~km}$ and (c) $10.02 \mathrm{~km}$ at 07 JST on 29 June. Vectors denote horizontal winds at the same height. Here, $z^{*}$ is defined as $z_{t}\left(z-z_{s}\right) /\left(z_{t}-z_{s}\right)$, where $z_{t}$ and $z_{s}$ are the surface height and the constant height of the model top, respectively.

$346 \mathrm{~K}$ are rarely found in the WP at the upper level (Fig. 18c). This shows that most of the cloud top heights of the convective cells in the WP were less than $10 \mathrm{~km}$.

The comparison of the predicted $\theta_{e}$ fields in Fig. 18, with those analyzed in Fig. 6 , shows a small difference in the $\theta_{e}$ contrast across the cold front in the lower layer between them. 
However, a similar $\theta_{e}$ gradient as that in the lower layer is found in the analyzed middle layer over the cold front (Fig. 6a), while the predicted $\theta_{e}$ distribution at the middle level is discontinuous over the cold front, and low $\theta_{e}$ air is predicted adjacent to the convective cells (Fig. 18b). This indicates that the intrusion rate of low $\theta_{e}$ air into convective cells may be directly related to the determination of their cloud top heights. The concept of convective instability explains that the inflow of low $\theta_{e}$ air in the middle layer enhances the unstable atmospheric condition. Meanwhile, the mixing of lifted high $\theta_{e}$ air from the lower layer, with intruded low $\theta_{e}$ air, decreases the buoyancy of the lifted air, and, consequently, convective cells may be suppressed to develop at a higher altitude.

As mentioned in Section 2, the middle-level $\theta_{e}$ air was very dry, but not colder than the surrounding atmosphere. This is ascertained from the simulation results of the $2 \mathrm{~km}-\mathrm{NHM}$ (not shown). Vertical cross sections of the predicted relative humidity across the cold front in the WP and the CP at 07 JST on 29 June are shown in Figs. 19a and 19b, respectively. Very dry air with relative humidity of less than $15 \%$, flowed into the layer between heights of $5 \mathrm{~km}$ and $8 \mathrm{~km}$. Since few convective cells developed to a height exceeding $10 \mathrm{~km}$ in the WP, dry air reached the southern side of the cold front (Fig. 19a). Meanwhile, many deep convective cells, arriving at the tropopause, are found in the CP (Fig. 19b). It is noted that dry air also existed on the southern side of the cold front in the CP. This is because some of the dry air from the west intruded into the convective cells, while the rest of it passed through the space between them. Therefore, this indicates that the $2 \mathrm{~km}$ NHM can resolve the convective cells. The manner in which the inflow of dry air determines the cloud top heights of convective cells, is examined in the following subsection.

\section{b. Factors to determine the cloud top heights of convective cells}

Figures 20a and 20b show the relative humidity field, and the normal component of the wind speed to the cold front, respectively, at a height of about $5 \mathrm{~km}$ at 07 JST on 29 June, predicted by the $2 \mathrm{~km}-\mathrm{NHM}$. The relative humidity upstream of both the $\mathrm{CP}$ and the WP is

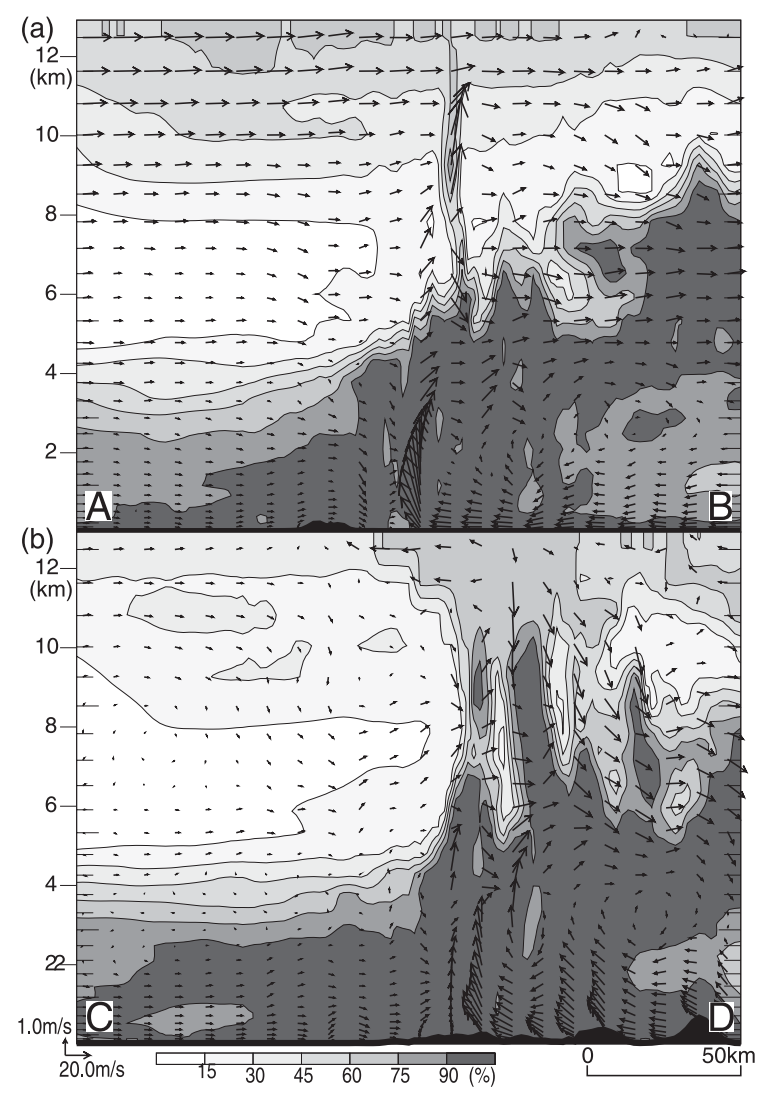

Fig. 19. Vertical cross section of relative humidity along lines (a) $\mathrm{AB}$ and (b) CD shown in Fig. 18b. Arrows show the wind vectors projected on these cross sections. The scale bar shown in the right-bottom side denotes the length in an abscissa.

between $15 \%$ and $30 \%$, and the difference between both sides is very little (Fig. 20a). The normal component of the wind speed to the cold front is between $6 \mathrm{~m} \mathrm{~s}^{-1}$ and $8 \mathrm{~m} \mathrm{~s}^{-1}$ in the $\mathrm{WP}$, and between $2 \mathrm{~m} \mathrm{~s}^{-1}$ and $4 \mathrm{~m} \mathrm{~s}^{-1}$ in the CP (Fig. 20b). Therefore, the inflow of middlelevel dry air flowing from the west to the CP, was less than half of that to the WP. This indicates that the intrusion of dry air into the convective cells was considerably larger in the WP than in the CP. The difference of this intrusion between the $\mathrm{CP}$ and the WP was also found from a height of $4 \mathrm{~km}$ to $9 \mathrm{~km}$ (see Fig. $19)$.

The pressure perturbation field, predicted by the $2 \mathrm{~km}-\mathrm{NHM}$, at a height of about $5 \mathrm{~km}$ at 07 

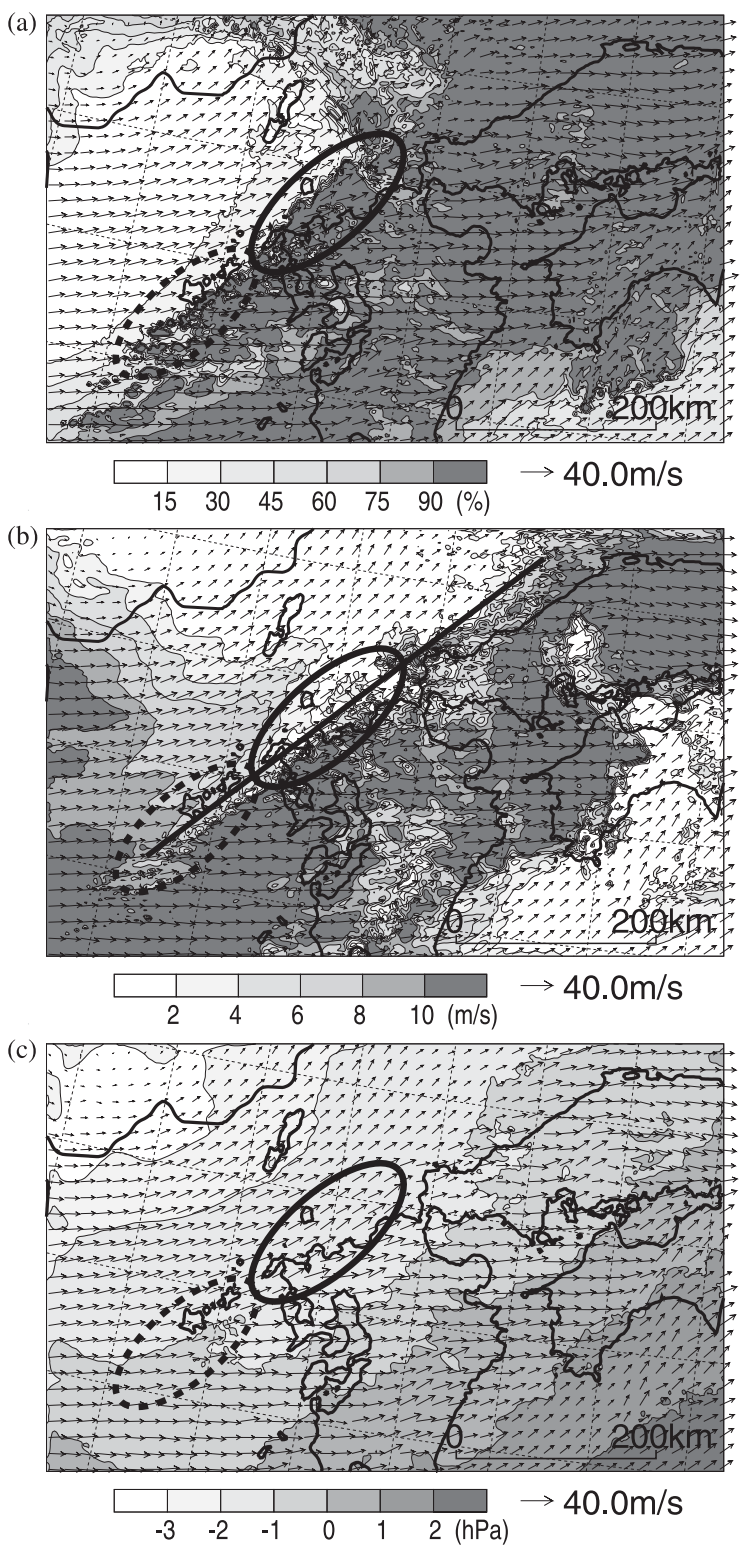

Fig. 20. Same as Fig. 18b, but for (a) the relative humidity, (b) the normal component of wind speed to the cold front shown by a bold line, and (c) the pressure perturbation from the hydrostatic balance. Positive values in (b) mean the wind speed to a south-east direction.

JST on 29 June, is shown in Fig. 20c. This field denotes the perturbation from the hydrostatic balance, but not the ageostrophic pressure field. Since the wind direction north of the cold front was parallel to the isobars, it was almost determined by the circulation ( geostrophic flow) of the meso- $\alpha$-scale low pressure. The ageostrophic wind component dominated in the areas where convective cells were simulated. This is because the winds there received strong influence of the diabatic heating, due to precipitation processes (not shown).

Therefore, the factors to determine the cloud top heights of the convective cells in the present heavy rainfall event could be summarized as follows. The amount of middle-level dry air inflow into the band-shaped precipitation system, was considerably larger in the WP than in the CP. This means that much cloud water evaporated around the cloud tops of convective cells in the WP, because of the significant intrusion of dry air. Consequently, further development of the convective cells was suppressed, due to the loss of buoyancy. Meanwhile, since most of the convective cells in the $\mathrm{CP}$ maintained their buoyancy in the middle layer, because of the slight intrusion of dry air, they were able to arrive at the tropopause. Here, it should be noted that the influence of dry air rapidly becomes small with height, because the atmosphere with lower temperature can contain less water vapor. Therefore, most of the convective cells that can maintain their buoyancy in the middle layer can arrive at the tropopause. Some convective cells in the CP, however, lost their buoyancy in the middle layer, such as those in the WP. This caused the appearance of two peaks in the cloud top heights of convective cells, as shown in Fig. 17.

Vertical cross sections of the $2 \mathrm{~km}-\mathrm{NHM}$ predicted buoyancy, across the cold front in the WP and the CP at 07 JST on 29 June, are shown in Figs. 21a and 21b, respectively. Since the buoyancy in the WP was negative over a height of $8 \mathrm{~km}$, the development of convective cells was suppressed below that height (Fig. 21a). Meanwhile, since the layer with positive buoyancy in the CP spread to a height of $12 \mathrm{~km}$, convective cells were able to develop to that height (Fig. 21b). Therefore, a large amount of dry air intrusion, found over a height of $4 \mathrm{~km}$, removed the buoyancy from the convective cells, and, as a result, some of them were not able to develop to a height exceeding $7 \mathrm{~km}$. Such convective cells are major in the WP, because a significant amount of dry air intruded into them. 


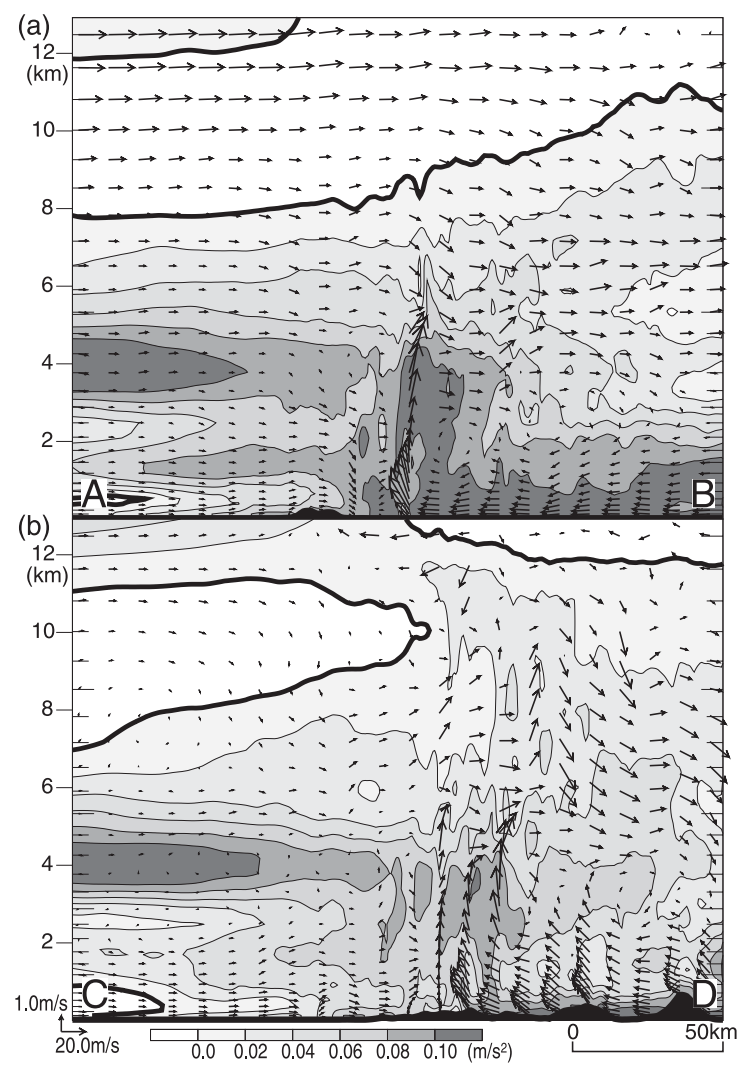

Fig. 21. Same as Fig. 19, but for the buoyancy. Thick lines denote the place where the buoyancy is zero.

\section{c. Sensitive experiments}

The processes whereby convective cells lost their buoyancy, due to the intrusion of middlelevel dry air, are examined by the two following sensitive experiments. One is an experiment without the evaporation of hydrometeors (NOEVP), and the other is an experiment without the diffusion term over a height of $3.5 \mathrm{~km}$ (NODIF). These experiments help understand the evaporation cooling effect of hydrometeors, and the mixing effect of dry air due to sub-grid-scale turbulences on the loss of buoyancy of convective cells.

The results of both NOEVP and NODIF showed the same characteristic features of the control experiment (CNTL, Fig. 17). The cloud top heights of convective cells were less than $7 \mathrm{~km}$ in the WP, and most of them were divided into two groups in the CP. This indicates that the buoyancy of some convective cells is lost at the middle level, even in the NOEVP. In fact (in the case of CNTL), the buoyancy is necessarily decreased by the evaporation cooling of hydrometeors, due to the intrusion of dry air into convective cells. Since such cooling does not occur in the NOEVP, another reason for the decrease of buoyancy needs to be considered. In the case of the NOEVP, the relative humidity in developing convective cells decreases due to the intrusion of dry air. Since this decrease of relative humidity suppresses the further condensation of water vapor, the buoyancy that convective cells gain after the intrusion of dry air is considerably decreased. However, this consideration does not completely explain the reason for the agreement of the results of NOEVP and CNTL. The agreement of the results of NODIF and CNTL indicates that the effect of sub-grid-scale turbulences on the loss of the buoyancy due to the intrusion of dry air into convective cells is small. The decrease of relative humidity around cloud tops of convective cells was brought, due to grid-scale mixing among adjacent grids, in the $2 \mathrm{~km}-\mathrm{NHM}$ simulation.

Here, the reason for the agreement of the results of NOEVP and CNTL is discussed. The $\theta_{e}$ of convective cells is conserved independently of the evaporation of cloud water and ice during a short time interval $\Delta t$ after the intrusion of dry air. The evaporation of the other hydrometeors is far smaller than that of cloud water and ice, because the drop of relative humidity due to the intrusion of dry air, during a $\Delta t$ is very small. This conservation of $\theta_{e}$ is the answer of the above question: the temperature of saturated air with the same $\theta_{e}$ can be uniquely determined when it is located at the same height.

The above-mentioned conservation of $\theta_{e}$ is illustrated using the schematic diagram shown in Fig. 22. Low-level humid air is lifted along the moist adiabat below the level of dry air inflow after it is saturated. Above that level, the lifted air is transported further upward with a temperature lapse rate that is less than that of the dry adiabat, and larger than that of the moist adiabat, due to the intrusion of dry air until it loses its buoyancy (e.g., from A to B, shown in Fig. 22). This transportation can be uniquely determined by the decrease of $\theta_{e}$, independently of the evaporation cooling of hydrometeors. Here, the process whereby the air located at $\mathbf{A}$ arrives at $\mathbf{B}^{\prime}$ for a $\Delta t$ is examined. 


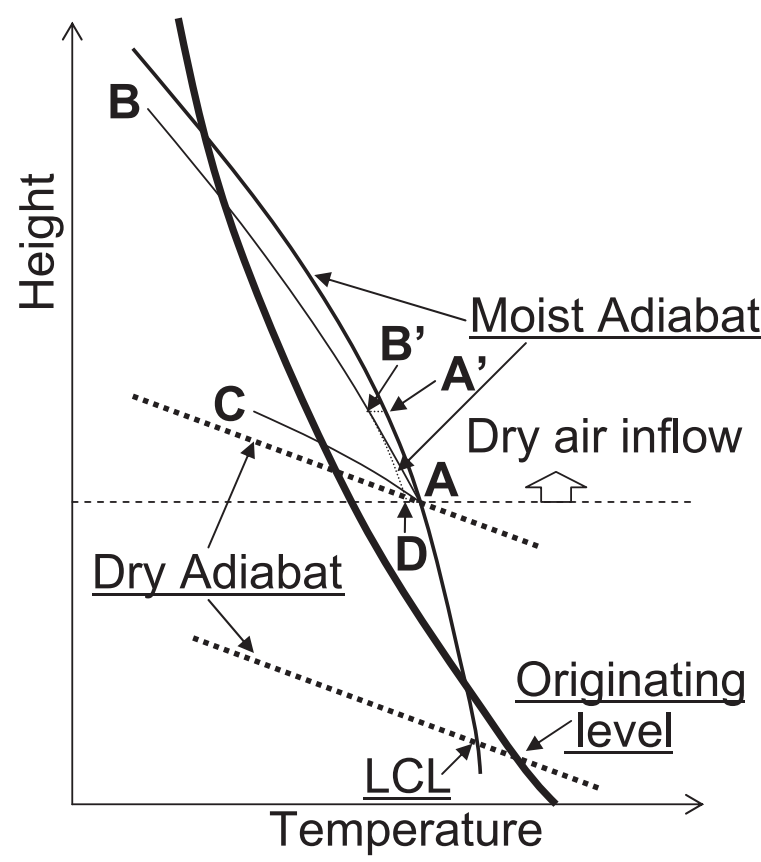

Fig. 22. Schematic diagram of the role of middle-level dry air inflow. The bold solid line denotes the temperature in the surrounding atmosphere. A humid air from an originating level is lifted along the moist adiabat below the level of dry air inflow, after it is saturated. Above that level, the lifted air is transported further upward with a temperature lapse rate less than dry adiabat one and larger than moist adiabat one until it loses its buoyancy (e.g., from A to B). When dry air inflow is a huge amount, the development of convective cells is strongly suppressed such the case as the curve A-C.

When no dry air intrudes into the convective cells, the air is lifted to $\mathbf{A}^{\prime}$ along the moist adiabat. In the case of CNTL, with the intrusion of dry air, the air located at $\mathbf{A}$ is cooled by the evaporation of hydrometeors, until it is lifted to the height of $\mathbf{A}^{\prime}$ and consequently arrives at $\mathbf{B}^{\prime}$ along the curve $\mathbf{A}-\mathbf{B}^{\prime}$. However, if hydrometeors were not evaporated (in the case of NOEVP), the air located at A could be lifted to $\mathbf{D}$ along the dry adiabat, until it was saturated again, and it could arrive at $\mathbf{B}^{\prime}$ along the moist adiabat. Therefore, although the process to determine the temperature of lifted air is different between the CNTL and the NOEVP, the temperature of lifted air at the same height can be uniquely determined because of the conservation of $\theta_{e}$ for a $\Delta t$.

When the dry air inflow is a very large amount, the development of convective cells is strongly suppressed, as in the case of the curve A-C, shown in Fig. 22. Therefore, Fig. 22 also indicates that the amount of dry air intruding into the convective cells, was the most significant factor to determine their cloud top heights.

\section{Conclusions and discussion}

A schematic diagram of the vertical structure of the band-shaped precipitation system, causing the heavy rainfall observed around the $\mathrm{Fu}$ kuoka area on 29 June 1999, is shown in Fig. 23. The cold front consisted of several MCSs, and each MCS consisted of a few convective cells, that successively formed on its upstream side. Each of them, the cold front, MCSs, and convective cells, had different spatial and time scales as well as different traveling speed and direction. Therefore, the precipitation system had a hierarchical structure with different horizontal scales. Under the atmospheric condition with strong convective instability, maintained by the inflows of low-level high $\theta_{e}$ air from the southwest, and middle-level low $\theta_{e}$ air from the west, the heavy rainfall was brought over the cold front. The middle-level low $\theta_{e}$ air was drier, not colder than that in the surrounding atmosphere. The amount of dry air intrusion into convective cells in the middle layer was considerably larger in the western part of the cold front than in the central part. This caused the difference in the cloud top heights of the convective cells; the convective cells were less than $7 \mathrm{~km}$ high in the western part, whereas, in the central part, most were between 5 and $7 \mathrm{~km}$ high and at the height of the tropopause.

The middle-level dry air inflow plays very significant roles in the maintenance of convective activities, and the determination of the cloud top heights of convective cells. These roles are summarized below. This dry air inflow results in the atmospheric condition with low $\theta_{e}$ in the middle layer, while the inflow of low-level humid air produces the atmospheric condition with a high $\theta_{e}$. These two inflows enhanced the convective instability, defined as $\partial \theta_{e} / \partial z<0$, between the middle and lower levels. Such a condition, with enhanced convec- 


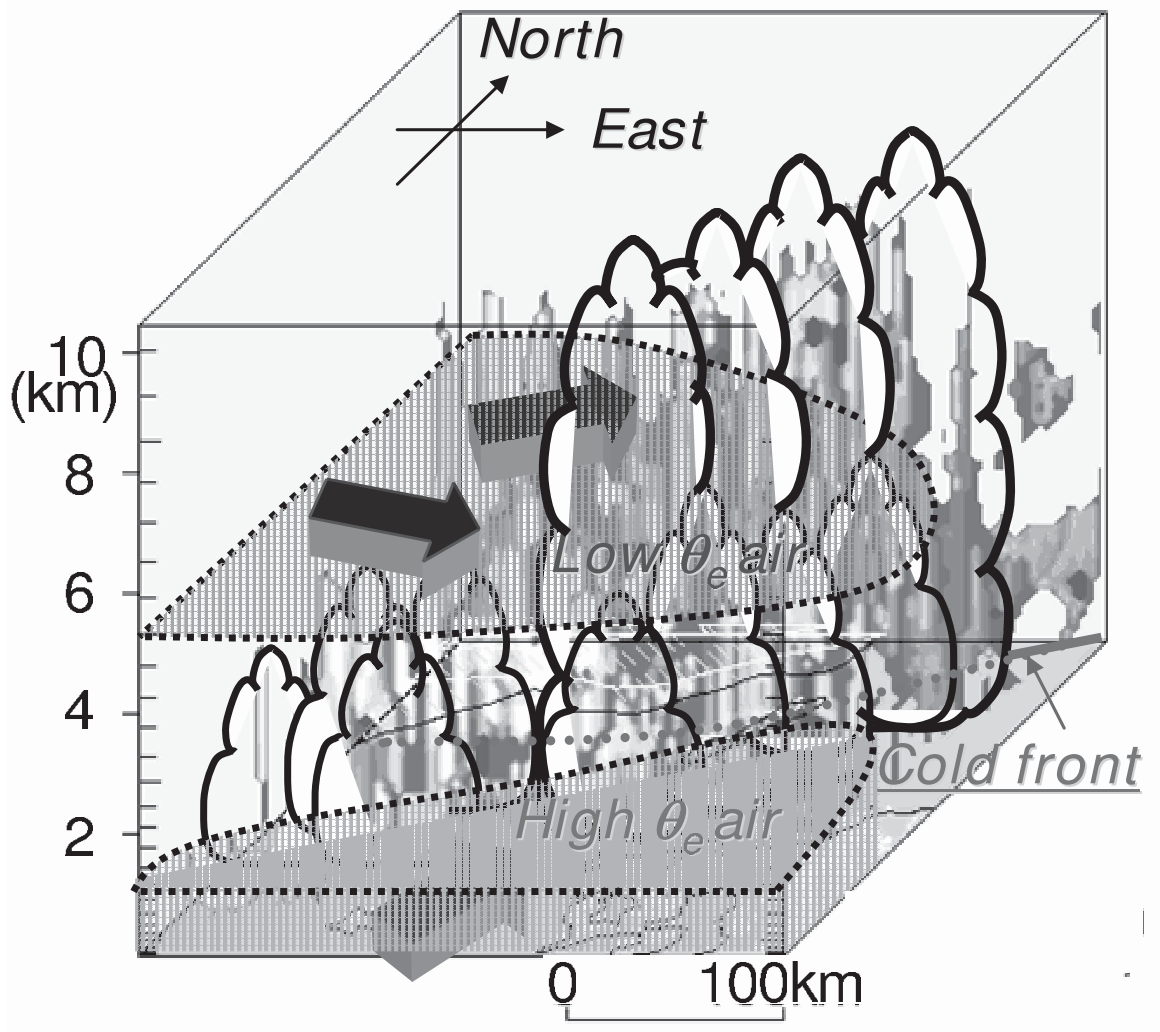

Fig. 23. Schematic diagram of the vertical structure of the band-shaped precipitation system causing the heavy rainfall observed around Fukuoka area on 29 July 1999, and the inflows of low-level low $\theta_{e}$ air, and middle-level high $\theta_{e}$ air into the precipitation system.

tive instability, is maintained whenever dry and humid air continuously flows into the middle and lower layers, respectively.

The middle-level dry air inflow decreases the buoyancy of convective cells, due to the evaporation cooling of hydrometeors. Meanwhile, this cooling also suppresses the complete stabilization of the latently unstable atmospheric condition. Consequently, the instability remains in the atmosphere. This is ascertained in the middle-level temperature field, predicted by the $2 \mathrm{~km}-\mathrm{NHM}$, in which the region around the band-shaped precipitation system is slightly colder, or not much higher than the surrounding area (see Fig. 24). This maintenance of the latent instability is important for the successive formation of convective cells. Therefore, the convective activities could be maintained in a case such as the present heavy rainfall. On the other hand, the moist atmospheric condition becomes neutral through the convective

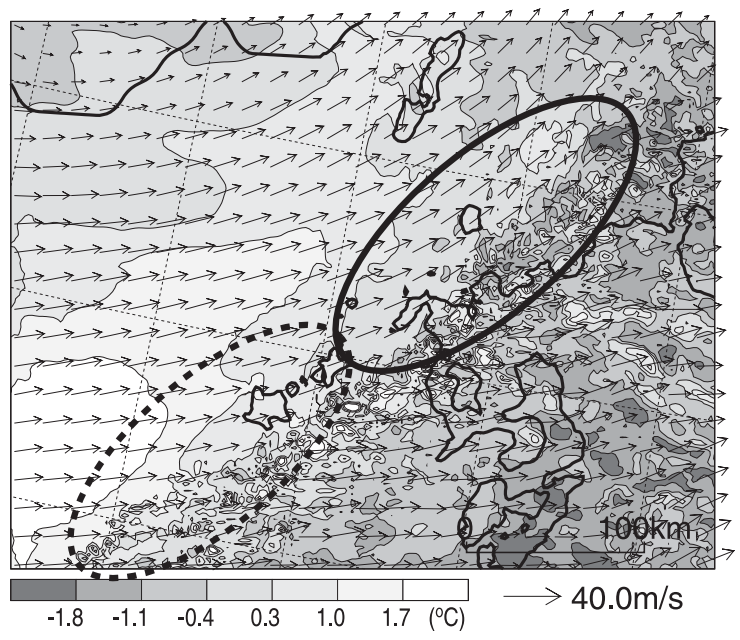

Fig. 24. Temperature field predicted by the $2 \mathrm{~km}-\mathrm{NHM}$ at a height of $5 \mathrm{~km}$ at 07 JST on 29 June. Vectors denote horizontal winds at the same height. 
activities, when middle-level dry air and lowlevel humid air are not supplied any longer. In such a case, the convective activities cannot be maintained. Further, the inflow of a large amount of middle-level dry air suppresses the development of convective cells, because convective cells lose their buoyancy due to the evaporation cooling of hydrometeors.

The above-mentioned explanations for the roles of middle-level dry air address different effects on convective activities. This is because a large amount of dry air inflow strongly enhances the convective instability, while the cloud top heights of convective cells continue to be suppressed by this inflow. The reason for the long-lasting suppression is discussed here. Since the evaporation of hydrometeors cools the atmosphere, horizontal divergence is generated there, due to the formation of high pressure. Under such a condition, the pressure gradient force, forming against the wind on the upstream side, results in the decrease of the dry air inflow. After the dry air inflow decreases sufficiently, convective cells may develop to the tropopause, because they maintain their buoyancy. Therefore, the suppression of the cloud top heights of convective cells could be temporary.

This consideration is examined in the present heavy rainfall case. Figure 25 shows the ageostrophic component of the pressure gradient force normal and parallel to the cold front, predicted by the $2 \mathrm{~km}-\mathrm{NHM}$ at a height of about $5 \mathrm{~km}$ at 07 JST on 29 June. In the normal direction (Fig. 25a), pairs of positive and negative values are found across the bandshaped rainfall area. Positive values to the downstream side of the rainfall area are much larger, and their area is much wider than that of negative ones to the upstream side. This is because the pressure became higher on the upstream side of the rainfall area, due to the larger intrusion of dry air. In the parallel direction (Fig. 25b), a positive area is widely found around the boundary, between the western and central parts of the cold front. This positive area was produced between the high pressure produced in the western part, and the low pressure in the central part. These positive gradient forces produced the outer flow from the convective cells in the western part of the cold front, mainly in the downstream direction.

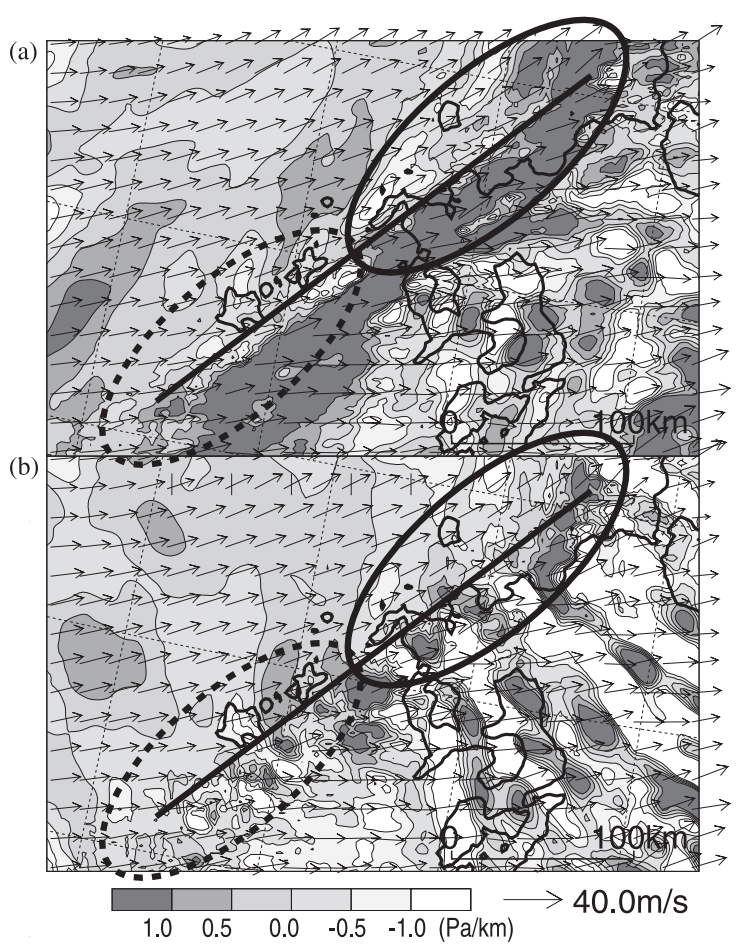

Fig. 25. Ageostrophic component of pressure gradient force (a) normal and (b) parallel to the cold front shown by a bold line in each panel, predicted by the $2 \mathrm{~km}-\mathrm{NHM}$ at $z^{*}=5.33 \mathrm{~km}$ at 07 JST on 29 June. The values were averaged using neighbor $7 \times 7$ grids. Positive values mean the acceleration to (a) a south-east and (b) north-east direction. Vectors denote horizontal winds at the same height.

Therefore, the development of convective cells continued to be suppressed under the level of dry air inflow in the western part.

In this study, two significant roles of middlelevel dry air on the convective activities were clarified; one is to maintain convective activities by not completely stabilizing the latently unstable atmospheric condition, and maintaining the instability, and the other is to suppress the development of convective cells. This influence of middle-level dry air rapidly becomes small with height, because the atmosphere with lower temperature can contain less water vapor. To examine the generality of these roles, ideal numerical experiments will be performed in the near future. 


\section{Acknowledgement}

The author is grateful to Dr. M. Yoshizaki, Dr. H. Seko, Mr. H. Eito and his colleagues of the Meteorological Research Institute (MRI) for their constructive comments. He also thanks two anonymous reviewers for their helpful comments. The X-BAIU-99 special observation was conducted mainly by the fund of Japan Science and Technology Corporation-Core Research for Evolutional Science and Technology. The numerical simulations in this study are performed using a Hitachi SR-8000 super computer system of MRI.

\section{Appendix}

\section{Relation between the latent instability and the convective instability}

The relation between the latent instability and the convective instability determined with two vertical levels is examined here. In order to compare these two different considerations, the difference in the equivalent potential temperature $\theta_{e}$, between $500 \mathrm{hPa}$ and $850 \mathrm{hPa}$ levels, which represents the convective instability, is compared with the Showalter Stability Index (SSI), which represents the latent instability. Here, the SSI is defined as the temperature difference at a $500 \mathrm{hPa}$ level between the environmental atmosphere and the lifted air adiabatically from an $850 \mathrm{hPa}$ level.

The $\theta_{e}$ can be approximately defined using the temperature $T$, the height from the $p_{0}$ $(=1000 \mathrm{hPa}$ ) level $z$, the mixing ratio of water vapor $q$, the Exner function $\Pi$, and $\Pi$ at the lifting condensation level $\Pi_{L}$ as

$$
\begin{aligned}
& C_{p} \theta_{e}=C_{p} T / \Pi+L q / \Pi_{L}, \\
& \Pi=\left(\frac{p}{p_{0}}\right)^{R / C_{p}}, \quad \Pi_{L}=\left(\frac{p_{L}}{p_{0}}\right)^{R / C_{p}},
\end{aligned}
$$

where $C_{p}$ is the specific coefficient for constant pressure, $g$ is the gravity acceleration, $L$ is the latent heat of evaporization, $R$ is the gas constant for dry air, $p$ is the pressure, and $p_{L}$ is $p$ at the lifting condensation level. From Eq. (A.1), the $\theta_{e}$ at a $500 \mathrm{hPa}$ level is expressed as

$$
C_{p} \theta_{e 500}=C_{p} T_{500} / \Pi_{500}+L q_{500} / \Pi_{L} .
$$

Here, the subscript denotes the pressure level. Since the $\theta_{e}$ of the air lifted adiabatically from an $850 \mathrm{hPa}$ level is conserved, the following equation is obtained:

$$
C_{p} \theta_{e 850}=C_{p} T_{500^{\prime}} / \Pi_{500}+L q_{s}\left(T_{500^{\prime}}\right) / \Pi_{500},
$$

where the $T_{500}$ is the temperature of the lifted air from an $850 \mathrm{hPa}$ level and $q_{s}(T)$ is the saturated mixing ratio of water vapor for $T$.

By subtracting Eq. (A.4) from Eq. (A.3), the following equation is obtained:

$$
\begin{aligned}
C_{p}\left(\theta_{e 500}-\theta_{e 850}\right) \\
=C_{p}\left(T_{500}-T_{500^{\prime}}\right) / \Pi_{500} \\
\quad+L\left(q_{500} / \Pi_{L}-q_{s}\left(T_{500^{\prime}}\right) / \Pi_{500}\right) .
\end{aligned}
$$

In the case of the latent instability, since $T_{500}$ is lower than $T_{500^{\prime}}, q_{500} / \Pi_{L}$ is smaller than $q_{s}\left(T_{500^{\prime}}\right) / \Pi_{500}$. This can be explained using the Clausius Clapeyron equation, and the relation between $p_{L}$ and the temperature at the lifting condensation level (not shown). Therefore, the following relation is obtained:

$$
\begin{aligned}
\theta_{e 500}-\theta_{e 850} & <\left(T_{500}-T_{500^{\prime}}\right) / \Pi_{500} \\
& <T_{500}-T_{500^{\prime}}<0,
\end{aligned}
$$

where $\Pi_{500}=0.823$. Equation (A.6) means that the atmospheric condition is often strongly convectively unstable, even when it is weakly latently unstable. The difference between $\theta_{e 500}-\theta_{e 850}$ and $T_{500}-T_{500^{\prime}}$ is determined mainly by $q_{500}$. In other words, this difference becomes larger as the air at a $500 \mathrm{hPa}$ level becomes drier.

\section{References}

Clark, T.L., 1977: A small-scale dynamic model using terrain following coordinate transformation. $J$. Comput. Phys., 24, 186-215.

Fritsch, J.M. and C.F. Chappell, 1980: Numerical prediction of convectively driven mesoscale pressure systems. Part I: Convective parameterization. J. Atmos. Sci., 37, 1722-1733.

Gadd, A.J. and J.F. Keers, 1970: Surface exchanges of sensible and latent heat in a 10-level model atmosphere. Quart. J. Roy. Meteor. Soc., 96, 297-308.

Gal-Chen, T. and R.C. Somerville, 1975: On the use of a coordinate transformation for the solution of the Navier-Stokes Equations. J. Comput. Phys., 17, 209-228.

Ikawa, M. and K. Saito, 1991: Description of a nonhydrostatic model developed at the Forecast Research Department of the MRI. Tech. Rep. of the MRI, 28, 238pp. 
Kain, J.S. and J.M. Fritsch, 1990: A one-dimensional entraining/detraining plume model and its application in convective parameterization. J. Atmos. Sci., 47, 2784-2802.

Kato, T., 1995: A box-Lagrangian rain-drop scheme. J. Meteor. Soc. Japan, 73, 241-245.

, 1998: Numerical simulation of the bandshaped torrential rain observed over southern Kyushu, Japan on 1 August 1993. J. Meteor. Soc. Japan, 76, 97-128.

and H. Goda, 2001: Formation and maintenance processes of a stationary band-shaped heavy rainfall observed in Niigata on 4 August 1998. J. Meteor. Soc. Japan, 79, 899-924.

, M. Yoshizaki, K. Bessho, T. Inoue, Y. Sato, and X-BAIU-01 observation group, 2003: Reason for the failure of the simulation of heavy rainfall during X-BAIU-01-Importance of a vertical profile of water vapor for numerical simulations-. J. Meteor. Soc. Japan, 81, 9931013.

, 2005: Characteristic features of the Baiu season from the view point of the synoptic scale, Meteor. Res. Notes, 208, 27-35 (in Japanese).

and K. Aranami, 2005: Formation factors of 2004 Niigata-Fukushima and Fukui heavy rainfalls and problems in the predictions using a cloud-resolving model. SOLA, 1, 1-4.

Kondo, J., 1975: Air-sea bulk transfer coefficients in diabatic conditions. Bound. Layer Meteor., 9, 91-112.

Numerical Prediction Division/Japan Meteorological
Agency, 2002: Outline of the operational numerical weather prediction of the Japan Meteorological Agency. 158pp. [Available from JMA, 1-3-4 Otemachi, Chiyoda-ku, Tokyo 100-8122, Japan.]

Saito, K., 1997: Semi-implicit fully compressible version of the MRI mesoscale nonhydrostatic model-Forecast experiment of the 6 August 1993 Kagoshima Torrential Rain-. Geophys. Mag. Ser. 2, 2, 109-137.

, T. Kato, H. Eito, and C. Muroi, 2001: Documentation of the Meteorological Research Institute/Numerical prediction Division unified nonhydrostatic model. Technical Reports of the MRI, 42, 133pp.

Sommeria, G., 1976: Three-dimensional simulation of turbulent processes in an undisturbed trade wind boundary layer. J. Atmos. Sci., 33, 216241.

Takahashi, T., 1984: Thunderstorm electrificationA numerical study. J. Atmos. Sci., 41, 25412558.

Yoshizaki, M., T. Kato, Y. Tanaka, H. Takayama, Y. Shoji, H. Seko, K. Arao, K. Manabe, and XBAIU-98 Observation Group, 2000a: Analytical and numerical study of the 26 June 1998 orographic rainband observed in western Kyushu, Japan. J. Meteor. Soc. Japan, 78, 835-856. , H. Seko, T. Kato, Y. Shoji, H. Eito, K. Bessho, H. Goda, and X-BAIU-99 Observation Group, 2000b: A report on a special observation of Baiu over East China Sea and Kyushu in 1999 (X-BAIU-99). Tenki, 47, 217-224 (in Japanese). 